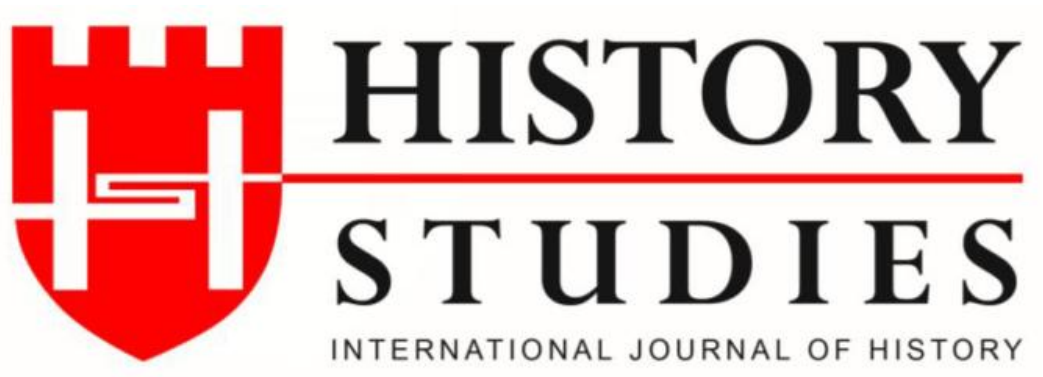

\author{
ISSN: 13094173 (Online) 1309 - 4688 (Print) \\ Volume 12 Issue 6, December 2020 \\ DOI Number: 10.9737/hist.2020.970 \\ Araştırma Makalesi
}

Makalenin Geliş Tarihi: 23.08.2020 Kabul Tarihi: 10.10.2020

Atıf Künyesi: Erol Yüksel - Sevgi Satı, “İkinci Dünya Savaşı'nda Türk Gazetecilerin Londra ve Berlin

Gezileri ve İzlenimleri (1939-1942)",History Studies, 12/6, Aralık 2020, s. 3399-3424.

\title{
İkinci Dünya Savaşı'nda Türk Gazetecilerin Londra ve Berlin Gezileri ve İzlenimleri (1939-1942)
}

London and Berlin Trips and Impressions of Turkish Journalists in the Second World War (1939-1942)

\author{
Dr. Erol Yüksel - Sevgi Satı \\ ORCID No: 0000-0003-3029-2342 / 0000-0003-2131-4642 \\ Karamanoğlu Mehmetbey Üniversitesi
}

\section{$\ddot{O ̈ z}$}

İkinci Dünya Savaşı başlangıcı, gelişimi ve sonuçları itibariyle birçok ülkeyi olduğu kadar Türkiye'yi de etkilemiştir. Muharip etkileri olmasa da özellikle dış politikasına yön veren birçok unsur, savaşın bu etkilerinden özellikle nasibini almıştır. Bu çerçevede savaş dönemi basını, bu etkilere yön veren bir propaganda aracı olarak öne çıkmıştır. Bir başka ifadeyle denge politikasıyla savaş dışı tutumunu kararlılıkla sürdüren ve muharip devletlerle ilişkilerine devam eden Türkiye, basını denetimli bir şekilde iç ve dış politikasında etkin şekilde kullanmıştır. Bu doğrultuda savaş dönemi Türk basınının önde gelen kalemleri, İngiltere ve Almanya'ya davetle ya da seçilerek geziler yapmışlardır.

Türkiye'nin gerek savaşın başlangıcı ve gelişiminde tutumunu etkilemek gerekse muharip lider devletlerin propaganda hedefleri doğrultusunda olduğu anlaşılan bu seyahatleri incelemek önemlidir. Bu makalede öncelikle savaş öncesi Türk basınının genel durumu, telif ve tetkik eserlerden istifade edilerek tanıtılmıştır. Daha sonra savaş öncesi Londra, Batı Cephesi günlerinde yeniden Londra, 1942 Berlin ve 1942 Londra gezileri, dönemin basını ve sonraki yıllarda hatıratlara yansıyan bilgiler ışığında değerlendirilmiştir. Ayrıca çalışmada Türk gazetecilerin 1939 ve 1942 yılları arasında yaptıkları Londra ve Berlin gezileri hakkında bütünsel bir bakış ortaya konmaya çalışılmıştır. Gezilere katılan gazetecilerin görüş ve izlenimleri, İkinci Dünya Savaşı'nda Türkiye'nin muharip devletlerle olan ilişkilerinin daha iyi anlaşılmasına katkı sunacaktır.

Anahtar Kelimeler: İkinci Dünya Savaşı, Londra Gezisi, Belin Gezisi, Türk Gazeteciler, Hüseyin Cahid Yalçın, Ahmet Emin Yalman.

\section{Abstract:}

Second World War also affected Turkey as many other countries in terms of its beginning, development and results. Although it didn't have combative effects, many factors that direct the country's foreign policy have been particularly affected by these effects of the war. In this context, the wartime press came to the fore as a propaganda tool that directed these effects. In other words, Turkey, who resolutely showed a non-combat stance with a 
İkinci Dünya Savaşı́nda Türk Gazetecilerin Londra ve Berlin Gezileri ve İzlenimleri (1939-1942)

balance policy and maintained relations with belligerent states, used the press in a controlled manner in the domestic and foreign policy effectively. In this direction, leading figures of the Turkish press during the war made trips to England and Germany by invitation or by election.

It is important to examine these trips because it is understood that their goal was to influence the attitudes of Turkey in the beginning and development of the war by using them as propaganda tools of belligerent states. In this article, first of all, the general situation of the Turkish press before the war was introduced by using copyright studies. Then, the pre-war London trips to London, 1942 Berlin and 1942 London again on the days of the Western Front were evaluated in the light of the press of the period and the information reflected in the memoirs in the following years. In addition, in the study, a holistic view of the London and Berlin trips of Turkish journalists between 1939 and 1942 was tried to be presented. The opinions and impressions of the journalists who participated in these trips will contribute to a better understanding of the relations between Turkey and belligerent states in the Second World War.

Keywords: Second World War, London Trip, Berlin Trip, Turkish Journalists, Hüseyin Cahid Yalçın, Ahmet Emin Yalman.

\section{Giriş}

İkinci Dünya Savaşı, muharip devletler için olduğu kadar muharip olamayanlar açısından da büyük öneme sahiptir. Özellikle jeopolitik konumundan dolayı hem Mihver hem de Müttefik devletlerin yanlarında savaşa girmesini istedikleri Türkiye, maruz kaldığı baskılara rağmen denge politikası izleyerek buna karşı koymayı başardı. Türkiye'nin izlediği bu denge politikası dış politikasında da bir takım değişikliklere neden oldu. Savaşın başında Müttefiklerden yana bir tavır alan Türkiye, İngiltere ve Fransa ile önce ayrı ayrı sonra da ortak deklarasyonlara imza attı. Alman başarılarının üst üste geldiği dönemde ise Almanya ile Dostluk ve Saldırmazlık Anlaşması imzalandı. Türkiye, Müttefikler safinda görülmekle beraber Almanya ile de iyi ilişkiler içindeydi. Dış politikada meydana gelen bu değişikliklerin temel nedeni Türkiye'nin savaş dışı kalma ve her iki tarafla da ilişkilerini sürdürme isteğiydi.

Hal böyle olunca dönemin basınında da politik yorumlarda farklılıklar ortaya çıktı. Bununla birlikte hükümetin basın üzerinde uyguladığı sansür o kadar fazlaydı ki değişen politikalara basın da ayak uydurmak zorunda kalıyordu. Bir başka deyişle basının durumu savaşın gidişatına göre yön değiştirmekteydi. Bu dönemde gerek Mihver gerekse Müttefik devletler, Türkiye'yi kendi yanlarında savaşa dâhil etmek için basını araç olarak kullandı ve Türk kamuoyunu etkilemeye çalıştı. Bu amaçla kendi askerî güçleri, savunma sistemleri ve savaş çalışmaları hakkında bilgi vermek için Türk gazetecileri kendi ülkelerine davet ettiler.

\section{1- İkinci Dünya Savaşı’nın Başında Türkiye ve Basın}

Birinci Dünya Savaşı 1918 'de sona ermesine rağmen özellikle Almanya'nın bu savaşın intikamını almak ve Versay anlaşmasından kurtulmak istemesi Avrupa devletleri arasındaki hesaplaşmaların tam olarak bitmesine engel teşkil etmekteydi. Almanya'da 1933 yılında iktidara gelen Hitler, Avrupa'yı egemenliği altına almak için güçlü bir ordu kurmaya başladı. Bunun üzerine İngiltere, Fransa, Rusya ve sonradan Amerika, Almanya’ya karşı Müttefik devletler grubunu oluşturdu. Almanya, Japonya ve İtalya ise Mihver grubunu meydana getirdi ${ }^{1}$.

Bu dönemde Türkiye-Almanya ilişkileri daha ziyade 1933 y1lından itibaren değişmeye başlamıştı. Hitler'in sınır değişikliklerinden bahsederek İtalya ile işbirliğini geliştirmesi ve

${ }^{1}$ Vahdettin Engin, "II. Dünya Savaşı ve Türkiye”, Yay. Haz. Nesrin Sarıahmetoğlu-İlyas Kemaloğlu, İkinci Dünya Savaşı ve Türk Dünyası, Türk Dünyası Belediyeler Birliği Yay., İstanbul 2016, s. 248-249. 
Boğazlar konusunda takındığı olumsuz tavır Türkiye'yi rahatsız etti. Fakat buna rağmen Türkiye, Almanya ile ekonomik işbirliğine devam etti. Çünkü savaşa giden bu süreçte Türk diş ticareti \%80-85 oranında ${ }^{2}$ Almanya'ya dayanıyordu. Almanya, Türkiye üzerinde ekonomik ve siyasi nüfuz kurarak Türkiye'yi Berlin-Roma Mihverine çekmek istedi. İtalya'nın 7 Nisan 1939'da Arnavutluk'u işgal ederek Balkanlara doğru ilerlemesi Türkiye'de İtalya'nın kendisine karşı bir yayılma politikası izlediği endişesini ortaya çıkardı. Bunun üzerine Türkiye, Akdeniz'de bir denge unsuru olarak İngiltere'nin yakınlığını aramaya başladı. Bu bağlamda 12 Mayıs 1939'da Türk-İngiliz Ortak Deklarasyonu imzaland13.

$\mathrm{Bu}$ deklarasyonla İngiltere ve Türkiye, Akdeniz'de barışı ihlâl edecek herhangi bir teşebbüse karşı ortak hareket etme kararı ald $_{1}{ }^{4}$. Fransa ile de Hatay sorunu kesin olarak halledildikten sonra, 23 Haziran 1939 'da Türkiye-Fransa Deklarasyonu imzalandi. Bu yeni deklarasyon, Türk-İngiliz deklarasyonunda yer alan hükümlerin neredeyse aynısını ihtiva etmekteydi ${ }^{5}$. Türk-Fransız deklarasyonundan tam bir ay sonra bütün dünyayı şok eden bir gelişme yaşandı. 23 Ağustos 1939 günü Almanya ile Sovyet Rusya arasında bir saldırmazlık paktı imzalandı. Hitler, Sovyetlerin tarafsızlığını sağladıktan sonra 1 Eylül'de Polonya'ya saldırarak İkinci Dünya Savaşını başlatan olayın fitilini ateşledi'. 19 Ekim 1939'da ise Akdeniz'de ortaya çıkan İtalyan tehlikesine karşı Türk-İngiliz-Fransız ittifakı imzaland1 ${ }^{7}$.

Savaşın hemen öncesi ve başlangıcındaki gelişmeler böyleyken Türkiye'nin savaşa girmeme ve denge politikası yürütme amacıyla biçimlendirdiği dış politikası, ülkede her alanda denetimin artmasına neden oldu. Bu denetimlerden etkilenenlerin başında da hiç şüphesiz basın gelmekteydi. Yürürlükte olan yasalar hükümetin basını denetlemesine ve yönlendirmesine olanak sağlyyordu'. Zira 25 Temmuz 1931'de kabul edilen Matbuat Kanunu ${ }^{9}$ hâlâ yürürlükteydi. Kanunun getirdiği en önemli kısttlama 50. maddeydi: Gazete ve dergilerde memleketin genel siyasetine dokunacak yayınlar olursa, İcra vekilleri heyeti kararıyla geçici olarak kapatılabilirdi ve kapatılan bir gazetenin sorumluları, kapatılması süresince başka bir adla gazete çıkaramazd $1^{10}$. Savaşın başlamasından bir süre sonra 24 Nisan 1940 'da ülkenin iç ve dış güvenliği konularında basının ileri gitmesini engellemek amacıyla Matbuat Kanunu'na iki madde daha eklendi. Maddelerin kapsamıla,ulusal duyguları inciten ve tarihini yanlış

${ }^{2}$ Şevket Süreyya Aydemir, İkinci Adam, C. II, Remzi Kitabevi, İstanbul 2011, s.68-69.

${ }^{3}$ Mücahid Özçelik, "İkinci Dünya Savaşı'nda Türk Dış Politikası", Erciyes Üniversitesi Sosyal Bilimler Enstitüsü Dergisi, 1.29 (2010), s. 254-255; Cemil Koçak, Türkiye'de Milli Şef Dönemi 1938-1945, C. I. , İletişim Yay., İstanbul 1996, s. 242-250; Fahir Armaoğlu, 20.Yüzyll Siyasi Tarihi, Timaş Yay. İstanbul 2016, s.320.

${ }^{4}$ TBMMZC, 6. Dönem, 2. Cilt, 12 Mayıs 1939, s. 67-72; Hüner Tuncer, İsmet İnönü'nün Dış Politikasl, 1938-1950, Kaynak Yay., İstanbul 2012, s.54.

${ }^{5}$ Osman Akandere, Milli Şef Dönemi, 1938-1945, İz Yay., İstanbul 1998, s. 271-272; Koçak, Türkiye'de Milli Şef Dönemi, C.I, s. 255-256; Tuncer, İsmet İnönü’nün Dış Politikası, s. 55; Armaoğlu, 20. Yüzyıl Siyasi Tarihi, s.320.

${ }^{6}$ Tuncer, İsmet İnönü'nün Dış Politikasl, s. 55.

${ }^{7}$ Haluk Ülman, “Türk Dış Politikasına Yön Veren Etkenler”, Ankara Üniversitesi SBF Dergisi, 23.3.1968, s. 251; Selim Deringil, Denge Oyunu İkinci Dünya Savaşında Türkiye’nin Dış Politikası, Tarih Vakfı Yurt Yay., İstanbul 2014, s. 96; Armaoğlu, 20. Yüzyll Siyasi Tarihi, s. 322; Fatih Aydoğmuş, İkinci Dünya Savaşı Sürecinde Propaganda ve Türkiye, (İstanbul Üniversitesi Atatürk İlkeleri ve İnkılâp Tarihi Enstitüsü, Yayımlanmamış Doktora Tezi), İstanbul 2018, s. 66.

${ }^{8}$ Gül Karagöz Kızılca, "1942 Yılında Mihver ve Müttefik Devletlerce Düzenlenen Türk Basın Gezileri”, Kebikeç, 14, 2002, s. 6.

${ }^{9}$ Nurettin Güz, Serbest Cumhuriyet Fırkası Sonrası Basında Muhalefet ve 1931 Matbuat Kanunu, Gazi Üniversitesi İletişim Fakültesi Basımevi, Ankara 1993, s.133.

${ }^{10}$ Alpay Kabacalı, Türk Basınında Demokrasi, TC Kültür Bakanlığı Yay., Ankara 1999, s. 153. 
gösteren yazılarla, ülkenin güvenliği hakkında yapılmakta olan soruşturmalardan ve güvenlik için alınan önlemlerden bahseden yazıların yayınlanması yasakland ${ }^{11}$.

Bu doğrultuda hükümet, savaşın başladığı 1939 yılı Eylül ayından 1944 yılı Ekim ayına kadar farklı gazete ve dergilere toplam doksan dört kapatma cezası verdi ${ }^{12}$. Falih R1fkı Atay, Ulus'ta bu durumu şöyle eleştirmiştir: Gazetecilerin iyileri sirf aşk yüzünden (gazetecilik aşkl) bu meslektedir. Ancak pekiyi bilirler ki talihleri bir telefon darbesine bağlıdır ${ }^{13}$. Atay'ın telefon darbesinden kastı, İçişleri Bakanlığının bir telefonla gazeteyi kapatmasıyd ${ }^{14}$. Ayrıca dış politikayla ilgili yazılar da kontrol altına alındı ve artık politika haberleri Anadolu Ajansından geldiği şekilde yayınlanmaya başland ${ }^{15}$. Burada basın sıkı bir denetim altına alınarak sürekli değişen askerî ve siyasi gelişmeler çerçevesinde yürütülen diş politika stratejisinin bu haber ve yorumlardan olumsuz yönde etkilenmemesi amaçland $1^{16}$.

Nitekim yıllar sonra dönemi yaşayan gazetecilerin hatıralarına basın üzerindeki bu kontrol ve bask1 yansımıştır. Bunlardan birisi Nadir Nadi'dir: Milli Şefe, hükümete ve CHP'ye dil uzatmak yasaktt. Hükümetin genel tutumu hiçbir şekilde tenkid edilemezdi. Bu itibarla gazeteler daha ziyade dünya politikası üzerinde durmaya önem veriyorlard... Gazetelerimiz, genel tutumlarını hükümet direktiflerine göre ayarlamak durumunda idiler ${ }^{17}$. Zekeriya Sertel de anılarında İsmet İnönü'nün Cumhurbaşkanı olduktan sonra “tek millet, tek parti, tek şef” diye bir sistem kurduğunu ve basını ele geçirdiğini belirtir: Basın bile onun elinde ve onun emrindeydi. Resmen sansür yoktu. Ama bakanlar ve Basın-Yayın Genel Müdürlüğ̈̈ hemen her gün gazetelere direktifler verirdi. Bu direktiflere uymayanların gazeteleri kapanmak tehlikesindeydi ${ }^{18}$.

Bununla birlikte Müttefik ve Mihver devletlerinin de basını izleme ve istihbarat servisleri, Türk basınını yakından takip ediyordu. Özellikle ünlü başyazarların ve dış politika gözlemcilerinin yazıları tek tek değerlendirilip gerekli görülenler yanıtlanıyordu. İngiltere'de "Review of the Foreign Press" yani "Dış Basından Seçmeler" dergisi, Türk basınından çevirdiği derleme ve yorumları yayımliyordu ${ }^{19}$.

Hükümetin basın üzerindeki bir başka denetim yolu ise büyük gazete sahipleri ve yazarlarının önemli bir kısmı Cumhuriyet Halk Partisi (CHP)'nin ya milletvekili ya da üyesi olmasıydı. Bu bakımdan dönemin Türk basınında öne çıkan; Yavuz Abadan, Falih Rıfkı Atay, Abidin Daver, Vedat Dicleli, Nihat Erim, Ahmet Şükrü Esmer, Sadi Irmak, Recep Peker, Necmeddin Sadak, Hamdullah Suphi Tanriöver, Ahmet Kutsi Tecer, Asım Us, Hüseyin Cahid Yalçın, Suut Kemal Yetkin gibi isimler hem gazeteci hem de CHP milletvekiliydi. Zaten 1939

\footnotetext{
${ }^{11}$ Ahmet Çelik, “İkinci Dünya Savaşı'nda Hükümet-Basın İlişkileri ve Gazeteci Mebuslar”, Fırat Üniversitesi Sosyal Bilimler Dergisi, C. 28, S: 2, Temmuz 2018, s.318; TBMMZC, 6. Dönem, 10. Cilt, 24 Nisan 1940, s.126-147.

12 Ali Cem Göz, "İkinci Dünya Savașı Yıllarında Türkiye'de Siyasal İktidar Tarafından Kapatılan Basın Organları Bağlamında Bir Listeleme Denemesi”, Süleyman Demirel Üniversitesi Vizyoner Dergisi, C.3, S: 5, 2011, s. 4-9; Tevfik Çavdar, Türkiye'nin Demokrasi Tarihi 1839-1950, İmge Kitabevi, 2. Bask1, Basım yeri ve yılı yok, s. 397.

${ }^{13}$ Falih Rifk1 Atay, “Gazeteci Mesleği”, Ulus, 29 Haziran 1938, s. 7.

${ }^{14}$ Hifzi Topuz, II. Mahmut'tan Holdinglere Türk Basin Tarihi, Remzi Kitabevi, İstanbul 2003, s. 162.

${ }^{15}$ Kızılca, "1942 Yılında Mihver ve Müttefik Devletlerce...”, s. 7.

${ }^{16}$ Abdullah İlgazi, “İkinci Dünya Savaşı'nın İç Politikadaki Yansımaları: Yaşanan Siyasi ve Ekonomik Sorunlar”, Eskişehir Osmangazi Üniversitesi Sosyal Bilimler Dergisi, Aralık 2019, 20 (2), s. 265; Orhan Koloğlu, Osmanlıdan Günümüze Türkiye'de Basın, İletişim Yay., İstanbul 1992,s. 67.

${ }^{17}$ Nadir Nadi, Perde Aralı̆̆ından, Çağdaş Yay., İstanbul 1979, s.24.

${ }^{18}$ Zekeriya Sertel, Hatırladıklarım, Remzi Kitabevi, İstanbul 2001, s. 208.

${ }^{19}$ Deringil, Denge Оуипи, s. 8.
} 
tarihli CHP tüzügünün 160. maddesi gereğince bu yazarlar parti menfaatlerine ve siyasetine uygun yayın yapmak ve hükümetin uygulamalarını halka benimsetmekle yükümlüydü ${ }^{20}$.

Savaş yıllarında Türkiye'de öne çıkan başlıca gazeteler; Cumhuriyet, Akşam, Vatan, Tan, Yeni Sabah, Tanin, Tasvir, Son Posta, Vakit, Ulus'tu' ${ }^{21}$. Hükümet, dönemin gazetelerinin genel politikalarını belirlemede büyük oranda söz sahibiydi. Bunun yanında Türk basını Alman, Müttefik ve Sovyet yanlısı olmak üzere üçe bölünmüş durumdaydı. Örneğin, CHP'nin resmi organı Ulus Gazetesinin Yazı İşleri Müdürü ve İngiltere'de dış politika uzmanı olarak büyük saygınlığı bulunan Ahmet Şükrü Esmer, Müttefikler lehine yazılar kaleme alırken aynı gazetenin diğer yazı işleri müdürü Falih Rıfkı Atay ise Mihver'in beklentileri yönünde yazılar yazmaktaydı. Cumhuriyet ve Tasvir-i Efkâr Alman yanlısı iken Akşam, İkdam ve Vakit orta yol bir politika izlemekteydi. Yeni Sabah, Haber, Tan, Son Telgraf ve Vatan belirgin şekilde Müttefik yanlısı, buna karşın Sertellerin Tan gazetesi ise Sovyet yanlısı ve Alman aleyhtariyd $1^{22}$.

Türk basınında genel durum savaşın seyrine göre değişmekteydi. Örneğin basın 1939 Mayıs'ından 1941 Mart'ına kadar Müttefiklere yakınken Almanların Türkiye sınırına dayandığı Mart 1941'den sonra Almanya'ya yakın bir tavir sergilemiştir. 1942'den sonra ise hem Mihvere hem de Müttefiklere 1lımlı mesajlar gönderilirken savaşta kazanan taraf belli olduktan yani Mayıs 1944'ten sonra da Müttefik yanlısı yayınlar yapılmıştır²3. Bütün bunların yanında başyazarların veya yazı işleri müdürlerinin kişisel görüşleri ne olursa olsun, hükümet tarafindan belirlenen sınırların dişına çıkmaları mümkün değildi ${ }^{24}$. Ayrıca bu dönemde savaşan taraflar Türkiye'de kendi propagandalarını yapan gazete veya dergiler çıkarıyorlardı. Do You Speak English, Parade, Images, Realite ve USA gibi farklı dergiler Müttefikler tarafindan destekleniyordu. Bunlara karşı1lı Fransızca yayın yapan Beyoğlu ve İstanbul, Türkçe Yeni Dünya ile Almanca Signal dergileri ve Turkische Post gazetesi de Alman yanlısı basının önde gelen örnekleriydi ${ }^{25}$.

Türk basınını kontrol etmeye çalışan Almanların ve Müttefiklerin ${ }^{26}$ amacı, basını kullanarak kamuoyunu etkilemek ve bu sayede Türkiye'nin kendi yanlarında savaşa katılmasını sağlamaktı. Türkiye'de gazetecilerin Mihver veya Müttefik gruplarından birini doğrudan destekleyen yayınlar yapmasına izin verilmemesine rağmen farklı gazeteci gruplar, savaşan devletler ile bunların işgali altındaki topraklara davet edildi ${ }^{27}$. Savaş boyunca yürütülen

\footnotetext{
${ }^{20}$ Barış Yetkin, "1945-1950 Arası Demokratikleşme Sürecinde Basın", Yakın Dönem Türkiye Araştırmaları, 17-18. 2010, s.5; Emre Bağce "Milli Şef Döneminde İktidar-Basın İlișkisi", Medya ve Siyaset 2:1923-1946 Tek Partili Dönem, Der., Tolga Yazıcı, Volga Yay., Kocaeli 2016, s. 102-103.

${ }^{21} \mathrm{H}$ ifzı Topuz, II. Mahmut'tan Holdinglere Türk Basın Tarihi, s. 170; Çelik, 'İkinci Dünya Savaşı'nda HükümetBasın İlişkileri, s. 319.

22 Özlem Yıldırım, “İkinci Dünya Savaşı Sürecinde Türk Basınında Mihver Taraftarlığı ve Hükümetin Bakışı”, Türk Basın Tarihi Uluslararası Sempozyumu, C. III., Atatürk Araştırma Merkezi Yayınları, Ankara 2018, s.1729-1730; Deringil, Denge Oyunu, s. 9; Seher Boykoy, II. Dünya Savaşı Yıllarında Türkiye'nin Sosyo-Kültürel Yapısı, (Dokuz Eylül Üniversitesi Atatürk İlkeleri ve İnkılâp Tarihi Enstitüsü, Yayımlanmamış Doktora Tezi), İzmir 2008, s.229.

${ }^{23}$ Yıldırım, "İkinci Dünya Savaşı Sürecinde Türk Basınında...", s. 1721; Bağce "Milli Şef Döneminde İktidar-Basın İlișkisi", s. 108.

${ }^{24}$ Deringil, Denge Oyunu, s. 9; Özellikle Falih Rıfkı Atay savaşın ilk günlerinden itibaren hükümetin sözcüsü olarak basına uyarılarda bulunmuş ve basını haber kirliliği karşısında dikkatli davranmaya çağırarak haberlerin süzgeçten geçirilerek verilmesi gerektiğini savunmuştur. Funda Selçuk Şirin, Falih Rıfk1 Atay (1893-1950), (Ankara Üniversitesi Sosyal Bilimler Enstitüsü, Yayımlanmamış Doktora Tezi), Ankara 2009, s. 430-431.

${ }^{25}$ Cavdar, Türkiye'nin Demokrasi Tarihi, s.399.

${ }^{26}$ Hıfzı Topuz, 100 Soruda Türk Basın Tarihi, Gerçek Yayınevi, İstanbul 1973, s. 164.

${ }^{27}$ Kızılca, "1942 Yılında Mihver ve Müttefik Devletlerce...", s. 7.
} 
propaganda faaliyetlerinin bir parçası olan bu geziler, kendi politik hedefleri doğrultusunda Türk kamuoyunu etkilemek ve yönlendirmek için yapılan girişimlerdi ${ }^{28}$.

Gazetecilerin İngiltere, Amerika, Almanya, Fransa gibi savaşa dâhil olan ülkelere çağrılmasının bir başka nedeni, sınırlarındaki savunma sistemleri, savaş çalışmaları ve askerî kuvvetlerini gelen gazetecilere yerinde gösterilmek istenmesi ve bu sayede faaliyetlerin Türk kamuoyuna aktarılmasını sağlamaktı ${ }^{29}$. Gezilere basını kendi dış politikaları doğrultusunda hükümetin yönlendirmesi olarak da bakabiliriz. Çünkü hükümet bu geziler için kendi politikasına uygun yayın yapan gazetecileri seçmekte ve her iki taraf arasında denge kuracak heyetler göndermekteydi. Örneğin Alman karşıtlığı ile bilinen Tan gazetesinden Zekeriya Sertel ve Hitler karşıtlığı ile bilinen Hüseyin Cahid Yalçın Müttefik devletlere yapılan gezilerde yer aldı. Yine Nadir Nadi Cumhuriyet gazetesinin İngilizlere yakın olduğu dönemde Müttefik devletlere düzenlenen geziye, Almanya'ya yaklaşıldığı dönemde ise Almanya'ya yapılan geziye katıldı. Ayrıca bu gezilerde gazetecilerin yapacakları harcamalar da devlet bütçesinden ${ }^{30}$ karşılamaktaydı. Denetimi sıkı tutmak isteyen hükümet gezilere bakanları, basın yayın genel müdürleri ve emekli askerleri de göndermişti ${ }^{31}$.

\section{2-Savaş Öncesi 1939 Londra Gezisi}

Türk-İngiliz deklarasyonunun 12 Mayıs'ta imzalanmasından yaklaşık on gün sonra Cumhuriyet'ten Abidin Daver, Ulus'tan Falih Rifkı Atay ve Burhan Belge, Vakit'ten Asım Us, Yeni Sabah'dan Hüseyin Cahid Yalçın ve Anadolu Ajansından Muvaffak Menemencioğlu'ndan oluşan bir grup gazeteci İngiltere'deki British Council Cemiyetinin ${ }^{32}$ daveti üzerine Londra'ya gitti ${ }^{33}$.

İlk defa bir grup hâlinde İngiltere'de tetkik seyahati yapmaya davet edilen Türk gazetecilerinden Asım Us, 23 Mayıs 1939'da başlayan ve yaklaşık 3 hafta süren bu gezi neticesinde İngiltere'yi daha yakından tanıma firsatı bulacaklarını düşünmektedir ${ }^{34}$. Us, Vakit'teki köşesinde, gazetecilerin davetinin Türk-İngiliz deklarasyonunun imzalanmasıyla alakalı olmadığını, İngilizlerin bu daveti yapmaya geçen yıl karar verdiklerini fakat bazı sebeplerden dolayı Türk gazetecilerin davetinin Mart ayı içinde yapılabildiğini ve o tarihte de henüz Türk-İngiliz anlaşmasının imzalanmadığını belirtmektedir. $\mathrm{Bu}$ nedenle Türk

\footnotetext{
${ }^{28}$ Yıldırım, “İkinci Dünya Savaşı Sürecinde Türk Basınında...”, s. 1725.

${ }^{29}$ Boykoy, II. Dünya Savaşı Ylllarında Türkiye’nin Sosyo-Kültürel Yapısı, s. 230; Hıfzı Topuz, 100 Soruda Türk Basin Tarihi, s. 164.

30 İngiliz belgelerine göre 1942 gezisine katılan gazeteciler devletin birer memuruymuşçasına günlük 1000 liralık harcırah almıştır. İngiliz Elçiliği bu bilgiyi Anadolu Ajansı müdüründen aldığını bildirmiştir. Aynı belgede Almanya'ya giden gazetecilerin de günlük 500 lira harcırah aldıkları belirtilmiştir. Kızılca, "1942 Yılında Mihver ve Müttefik Devletlerce...", s.7-8.

${ }^{31}$ Kizılca, "1942 Yılında Mihver ve Müttefik Devletlerce...”, s. 7-9; 1940 Londra seyahatine gazetecilerin yanı sira İstanbul Mebusu emekli General Refet Bele, Eski Müdafaa Vekili General Naci Tınaz, Samsun Milletvekili emekli Amiral Fahri Ergin, Anadolu Ajansından Muvaffak Menemencioğlu, Başvekâlet Matbuat Umum Müdürü Selim Rauf Sarper, Albay Rıza Yavuzalp, Matbuat Umum Müdürlüğünden Şekip Engineri gibi isimler de katılmıştır. Koçak, Türkiye'de Milli Şef Dönemi, C.I, s. 301-302.

32 1934'te "The British Committee for Relations with Other Countries" adıyla kurulan ve daha sonra adı "British Council" olarak kısaltılacak yapılanma; İngilizcenin desteklenmesi için yurt dışındaki üniversitelere burs tahsis edilmesi, yurt dışında Britanya kütüphanelerinin kurulması, seçkin Britanyalı konuşmacıların katıldığı seminerler dizisinin düzenlenmesi, önde gelen gazeteci ve profesyonellerin İngiltere'yi ziyaret etmeleri için destek olunması ve film gösterimleri olmak üzere beş başlıkta faaliyet göstermektedir. Ahmet Erman Aral, Kültür Propagandasindan Kültürel Diplomasiye: British Council'in Türkiye'deki Faaliyetlerinin 1940-1950 ve 2005-2014 Dönemlerinde Karşılaştırmalı Incelemesi, (Hacettepe Üniversitesi Sosyal Bilimler Enstitüsü, Yayımlanmamış Yüksek Lisans Tezi), Ankara 2014, s. 24.

${ }^{33}$ Vakit, 14 Haziran 1939, s.1.

${ }^{34}$ Asim Us, "Londra Yolunda", Vakit, 29 Mayıs 1939, s. 1,8.
} 
gazetecilerin Londra gezisi, anlaşma zamanına tesadüf ettiği için doğal olarak iki ülke arasındaki ilişkilerin samimiyetini ${ }^{35}$ artırmaktadır.

Gazeteciler İngiltere'de gördükleri misafirperverliği ve İngilizlerin geziden duydukları memnuniyeti her firsatta dile getirerek, bunu övgüyle gazetelerindeki köşelerine yansıtmışlardır. Örneğin Cumhuriyet’ten Abidin Daver, daha ilk temaslarımızda Türkiye'nin sulh cephesinde, Ingiltere'nin yanında yer almış olmasının Ingiltere'de ne kadar büyük bir memnuniyet ve hatta şükran hissi uyandırdı̆̆ını gördük ${ }^{36}$ izlenimindedir ve kendilerine gösterilen fevkalade misafirperverliğe ve samimiyete teşekkür etmiştir ${ }^{37}$. Yine benzer şekilde Yeni Sabah'tan Hüseyin Cahid Yalçın İngiltere'de kendilerini en çok duygulandıran şeyin gördükleri samimiyet ve muhabbet olduğunu belirtmiştir: Bunda bizim kalbimizi celbeden nokta bütün bu sempati tezahürlerinin bizim şahıslarımıza değil, vatanımıza taallük ettiğini düşünmekti. Çünkü yapılan ikram, inkılâp Türkiye'sinin kazanmış olduğu takdir ve hayranlık hislerinin bir tezahürü idi ${ }^{38}$. Falih Rıfk1 Atay Ulus'ta, Ingilizlerin Türkiye'den kendi memleketlerine gelen birkaç misafire azami nezaket göstereceklerine şüphe yoktu. Fakat bizim gördügümüz muamele tabii nezaket haddini çok aştı̆̆1 gibi bir izlenimle memnuniyetini yansıtır. Atay'a göre gazeteciler bu muameleyi kendilerine gösterilmiş gibi anlamamalıdır. Çünkü bu durum Türk milletine, İngilizlerin duyduğu derin güven ve sevgisinin eseridir ${ }^{39}$. Yine Ulus gazetesinden Burhan Belge kendilerine, Bir heyet idik ki kudretli ve sulh dostu Türkiye'den geliyorduk. dediği yazısında İngiltere'de gördükleri sıcak ve samimi havadan bahsetmekte ve İngiliz basınının Türk gazetecilerin ziyaretinden dolayı geniş kapsamlı ve dostça yazılar yazdıklarını ifade etmektedir ${ }^{40}$. Asım Us Vakit'teki köşesinde yazdığı yazısında Türk gazetecilerin Londra'da gördükleri misafirperverliği ancak İngiltere'nin Türk dostluğuna verdiği büyük kıymetten ve Türk milletinin karakterine gösterdiği güvenden kaynaklandığını düşünmekte ve böylesine bir müşahededen dolayı Türk milletinin gerçekten iftihar etmesi gerektiğini belirtmektedir ${ }^{41}$.

Volume 12

Issue 6

December

Gezi sırasında İngiltere'nin Portland şehrinde bulunan İngiliz donanmasını gezen gazeteciler burada savaş silahlarının en gizli unsurlarına şahit oldular. Yine Colchester'deki İngiliz askerî mevkiinde sadece ordu mensuplarının bulunmalarına izin verilen talimleri takip ettiler ve daha sonra İngiliz Başvekili Chamberlian tarafından kabul edildiler ${ }^{42}$ İngiliz devlet adamlarının savaş istemediğini ve her firsatta barıștan bahsettiğini belirten Burhan Belge, buna karşın halkın barıştan pek ümitli olmadığı düşüncesindedir: İngiliz devlet adamları sulhtan bahsediyorlar. Harp istemediklerini söylüyorlar... Fakat Ingiliz'in kendisi sokaktaki adamdan tuttuğunuzda davetinin kusursuz cereyan etmesi için bir umum müdür kadar hazırlıkl ve dikkatli davranan ladyye kadar herkes harbi soğukkanlılıkla beklemektedir. Ingiliz milletinin sulhtan pek ümidi yoktur ${ }^{43}$. Asım Us ise bu konuda şunları söylemektedir: İhtiyar Çemberlayn dünya milletlerini büyük bir harbin felaketlerinden korumak yolunda elinden geleni yaptyor. Fakat ayn zamanda harp hazırlıklartna azami kuvvet ve sürat veriliyor ${ }^{44}$. Hüseyin Cahid

\footnotetext{
${ }^{35}$ Asım Us, "İftihara Değer Müșahedeler”, Vakit, 14 Haziran 1939, s. 1-2.

${ }^{36}$ Abidin Daver, "Londra'da Karşılaştığımız Hava", Cumhuriyet, 5 Haziran 1939, s 3.

${ }^{37}$ Abidin Daver, "Üç Portre", Cumhuriyet, 16 Haziran 1939, s. 5.

${ }^{38}$ Hüseyin Cahid Yalçın, “İngiltere'de Türk Gazetecileri”, Yeni Sabah, 18 Haziran 1939, s. 3.

${ }^{39}$ Falih Rifk1 Atay, "Umumi Hava", Ulus, 23 Haziran 1939, s. 1.

${ }^{40}$ Burhan Belge, "Londra'ya Varış", Ulus, 23 Haziran 1939, s.2.

${ }^{41}$ Asım Us, "İftihara Değer Müşahadeler", Vakit, 14 Haziran 1939, s. 1-2.

42 Asım Us, "İftihara Değer Müşahadeler", Vakit, 14 Haziran 1939, s. 2.

43 Burhan Belge, "İngiltere Silahlanıyor", Ulus, 1 Temmuz 1939, s. 2; Aytaç Yıldız, Burhan Asaf Belge: Cumhuriyetin Erken Döneminde Aydın ve İktidar İlişkisi, (Ankara Üniversitesi Sosyal Bilimler Enstitüsü, Yayımlanmamış Doktora Tezi), Ankara 2009, s.25.

${ }^{44}$ Asim Us, "Harbe mi Sulha mı?", Vakit, 8 Haziran 1939, s. 1-2.
} 
Yalçın, İngiliz devlet adamlarının barış adına gösterdiği çabayı hayranlık uyandıracak derecede bulur. Bununla birlikte özellikle İngiliz Başvekil ve Hariciye Nazırının devletlerarası barış ve sükûnu sağlayabilmek için ikna siyaseti yaptıklarını fakat bunun bir netice vermediğine şaşırmaktadır: Bu kadar devamlı ve esaslı bir sulh ve müsalemet emelinin hiçbir netice tevlit edememesi hakikaten akıl ve mantığın alamayacă̆ bir garabettir ${ }^{45}$. İngiliz Başbakanının, İngiltere'nin sulhu muhafaza için her türlü fedakârlı̆̆ yaptı̆̆ını buna rağmen sulhu korumak mümkün olmazsa artık mesuliyetin İngiltere ye ait olmayacağın söylediğini dile getiren Abidin Daver de İngiltere'nin barışı korumak için gayret gösterdiğini düşünenler arasındadır ${ }^{46}$.

Gazeteciler seyahat sirasında Olympia salonundaki Military Tour-ament programına katılarak burada İngiltere'nin savunma aracı balonlarını yakından görme firsatı elde ettiler. Savaş çıkması hâlinde İngilizler, 8 milyonluk Londra şehrinin etrafını havadan, aralarında 100 'er metre mesafe ve yerden 6 bin metre yüksekte yer alan ve çelik tellerle yere bağlanacak bu balonlar ile bir kale gibi öreceklerdi. Heyet, zengin kıyafetli muhafız kıtalarından, 12-13 yaşındaki üniformalı çocuklara, süvarilerden tanklara ve muharebe atışlarına kadar İngiltere'nin yeni askerî çehresine şahit oldu ${ }^{47}$.

Burhan Belge'ye göre bu gösterilerdeki amaç, İngiliz savunma silahlarının en son tiplerini göstermek ve bu suretle hem devlet adına bir tek hesap vermek hem de halkın askerliğe olan ilgisini artırmaktır. Belge, halka millî müdafaa terbiyesi ve sevgisi aşıladığını düşündüğü bu gösterilerin bir geçit töreni kadar ciddi ve faydalı olduğunu düşünmektedir ${ }^{48}$. Falih Rıfk1 Atay’a göre bu program, milleti yeni askerlik havasına isındırmak, halkı ordu ile kaynaştırmak amacıyla düzenlenmişti ${ }^{49}$. Neticede temaslarını tamamlayan gazeteciler 14 Haziran 1939 günü Türkiye'ye döndü ${ }^{50}$.

\section{3- Batı Cephesi'nde Alman Taarruzu Günlerinde Londra Gezisi}

Gazetecilerin yurda dönmesinden yaklaşık iki buçuk ay sonra Almanya, işgal hareketlerine başlayarak 1 Eylül 1939 günü Polonya'yı işgal etti. Bunun üzerine İngiltere ve Fransa, Almanların Polonya'dan çekilmesini istedi. Fakat verdikleri ültimatoma cevap alamayınca 3 Eylül 1939'da Almanya'ya savaş ilan ettiler. Böylece İkinci Dünya Savaşı başladı ${ }^{51}$.

Savaş başladığında Türkiye'nin temel politikası, millî egemenliğine ve toprak bütünlüğüne zarar gelmeden savaş tehlikesini atlatabilmekti. Türkiye bu süreçte kendisini savaşa sokabilecek düzenlemelerden kaçınarak Avrupa'da ortaya çıkan Mihver ve Müttefik gruplarına dâhil olmadan sınır güvenliğini sağlamaya çalışt1 ${ }^{52}$. Savaş süresince de "ne olursa olsun savaşal katılmamak" ilkesi doğrultusunda bir dış politika takip etti. Amaç güçlü devlete eğilim göstererek ülkenin savaştan uzak tutulmasını sağlamaktı. Bu amaca ulaşmak için farklı diplomatik taktikler uygulanmasına karşın temel prensipleri hiç değiştirmeyerek savaş süresince bir "denge" politikası izledi ${ }^{53}$. Buradaki temel düşünce büyük fedakârlıklarla kurulan devlet, Avrupa'nın kendi yarattığı bir savaş uğruna tehlikeye atılamazdı. Çünkü Türkiye'nin

\footnotetext{
${ }^{45}$ Hüseyin Cahid Yalçın, "Sulhe Varmak İçin”, Yeni Sabah, 17 Haziran 1939, s. 1.

${ }^{46}$ Abidin Daver, "Üç Portre", Cumhuriyet, 16 Haziran 1939, s. 5.

${ }^{47}$ Asım Us, "Harbe mi Sulha mı?", Vakit, 8 Haziran 1939, s. 1-2; Falih Rifk1 Atay, “Asker İngiltere”, Ulus, 25 Haziran 1939, s.8.

${ }^{48}$ Burhan Belge, "İngiliz Balilla'ları", Ulus, 26 Haziran 1939, s.2

${ }^{49}$ Falih Rifk1 Atay, “Asker İngiltere”, Ulus, 25 Haziran 1939, s.8.

${ }^{50}$ Vakit, 14 Haziran 1939,s.1.

${ }^{51}$ Engin, "II. Dünya Savaşl ve Türkiye”, s. 248-249.

${ }^{52}$ Mustafa Aydın, "İkinci Dünya Savaşı ve Türkiye1939-1945”, Edt. Baskın Oran, Türk Dış Politikası, C.I, İletişim Yay., İstanbul 2009, s.399; Ülman, "Türk Dış Politikasına Yön Veren Etkenler", s. 245.

53 Akandere, Milli Şef Dönemi, s. 269; Baskın Oran,"Savaş Kaosunda Türkiye, Göreli Özerklik-2”, Türk Dlş Politikası, Edt. Baskın Oran, İletişim Yay., İstanbul 2009, s. 396.
} 
hiçbir toprak ve uluslararası ilişkilerde yerinin yeniden değerlendirilmesi gibi bir talebi yoktu ${ }^{54}$. Türkiye, bir saldırıya uğramadığı sürece savaşa katılmayacaktı ${ }^{55}$. Hükümetin tarafsız kalma kararını Türk kamuoyu da desteklemekteydi ${ }^{56}$.

İngilizler, Türk basınını kullanarak kamuoyu oluşturma ve Türkiye'yi kendi yanında savaşa dâhil etme amaçlarının bir tezahürü olarak bir Türk heyetini İngiltere'ye davet etti. Yine British Council tarafindan davet edilen 6's1 gazeteci milletvekili, üçü sadece milletvekili, üçü sadece gazeteci, matbuat ve ajans umum müdürleri, Matbuat Müdürlüğü'nden bir müşavir ve imalat-1 harbiyeden bir müdür olmak üzere 16 kişilik bir heyet 7 Mayıs 1940 günü İstanbul'dan hareket etti ${ }^{57}$.

Bu defaki seyahate İstanbul milletvekili emekli General Refet Bele, Yeni Sabah'tan Hüseyin Cahid Yalçın, eski Müdafaa Vekili General Naci Tınaz, Sinop Milletvekili Amiral Fahri Ergin, Albay Rıza Yavuzalp, Ulus'tan Falih Rıfkı Atay ve Ahmet Şükrü Esmer, Akşam 'dan Necmettin Sadak, Anadolu Ajansı Umumi Müdürü Muvaffak Menemencioğlu, Vakit gazetesinden Asım Us, Matbuat Umum Müdürü Selim Rauf Sarper, Matbuat Umum Müdürlügünden Şekip Engineri, Cumhuriyet'ten Nadir Nadi, Yeni Asır'dan Şevket Bilgin, Nevzat Celal, Ziya Gevher Etili katıld1 ${ }^{58}$.

Heyet ilk durağı olan Paris'e vardığı gün Almanya; Hollanda, Belçika ve Lüksemburg üzerine büyük bir taarruz hareketine başlamıştı ${ }^{59}$. Anılarında anlattıklarına bakılırsa Nadir Nadi, heyetin bu olayı yakından görmesi heyecanla karşılanır: Demek beklenen gün gelmiş, ateş nihayet Batı Cephesini de sarmıştı. Tuhaf savaşa paydos diyorduk artık. Heyecanlı günler yaşayacaktık. Olayların içinde bulunmak son derece hoşuma gidiyordu ${ }^{60}$. Buna karşın Almanların taarruz harekâtı, heyet arasında seyahate devam edilip edilmemesi konusunda tartışmalara neden olmuştur. Sonuçta seyahate devam etme kararı alındı. Asım Us'a göre Türk heyetinin savaşa rağmen geri dönmeyip seyahat kararı vermesi İngiltere'de Türklerin taahhütlerine sadakat gösterdikleri şeklinde yorumlanmışt ${ }^{61}$.

Böylesi bir durum karşısında Türk heyetinin Türkiye’ye döneceği haberleri İtalyan radyosundan duyurulur. Ahmet Şükrü Esmer, bu garip haberiBritish Council'in başkanı Lord Loyd'un vediği çay ziyafetinde, bizzat Loyd'dan duyduklarını belirtir. Fakat Loyd, habere inanmaz: Ben bu haberi aldı̆̆ım zaman inanmamıştım. Çünkü Türklerin asla geri dönmediklerini bilirim. İtalyan radyosundan sonra Alman radyosundan da ayn asılsız haberin verildiğini belirten Esmer, her iki radyonun da rolünün yalan ve yanıltıc1 haberler yapmak olduğunu bildikleri için böyle bir habere şaşırmamışıır ${ }^{62}$. Bu asılsız haberlere bakılırsa Berlin Roma Mihveri, Türk heyetinin gezisinden rahatsızdır.

Sonraki gün Loyd ve İngiliz General Sir Horald Alexander'ın Türk heyetine verdiği yemekte Alexander, heyetin seyahate devam edip edemeyeceğinden endişelidir: Bir an seyahatinizde devam etmeyeceğinizden korktuk. Şimdi bu korkumuzdan sıkllyoruz ${ }^{63}$. Fakat

\footnotetext{
${ }^{54}$ Deringil, Denge Oуиии, s. 5.

${ }^{55}$ Tuncer, İsmet İnönü'nün Dış Politikası, s.75.

${ }^{56}$ Nadi, Perde Aralığından, s. 112.

${ }^{57}$ Ahmet Şükrü Esmer, "Bir Seyahat'in Notları", Ulus, 2 Haziran 1940, s.3.

${ }_{58}$ Asım Us, Hatıra Notları,(Haz. İsmail Dervişoğlu), Kitabevi, İstanbul 2012, s. 398; Cumhuriyet, 8 Mayıs 1940, s.1; Nadi, Perde Aralı̆̆ından, s. 83; Koçak, Türkiye'de Milli Şef Dönemi, C.I, s. 301.

59 Asım Us, “Taarruz Haberi Paris'te Nasıl Duyuldu?”,Vakit, 19 Mayıs 1940, s.1; Koçak, Türkiye'de Milli Şef Dönemi, C.I, s. 302; Uçarol, Siyasi Tarih, s. 597.

${ }^{60}$ Nadi, Perde Aralığından, s. 89.

${ }^{61}$ Us, Hatıra Notlarl, s. 396; Asim Us, 1930-1950 Hatıra Notlarl, Vakit Matbaası, İstanbul 1966, s. 434.

${ }^{62}$ Ahmet Şükrü Esmer, "Bir Seyahat'in Notları”, Ulus, 3 Haziran 1940, s.3.

${ }^{63}$ Falih Rifkı Atay, “Ceb’e Doğru”, Ulus, Haziran 1940,s. 2.
} 
Alexander, zor şartlara rağmen seyahati yarıda bırakmayan bütün heyeti tebrik etmiştir: Lord Alexander Çanakkale'de gögüs göğ̈̈se çarpışmak suretiyle kahramanlı̆̆ımızın derecesini herkesten daha iyi ölçmüş bulunduklarını bu itibarla hakkımızdaki his ve duygularının diğer milletlere nazaran daha samimi daha içten geldiğini ileri sürd $\ddot{u}^{64}$.

$\mathrm{Bu}$ asılsız haberin yansıması böyleyken Almanya'nın 10 Mayıs'ta Hollanda, Belçika ve Lüksemburg üzerine başlattığı harekâtı Türk gazetecileri, genellikle bu devletlerin gafil avlandıkları ve tarafsızlığa körü körüne bağlı kalarak hata yaptıkları şeklinde yorumladılar. Asım Us'a göre Avrupa savaşının kaderi Batı Cephesi'nde dügümlenmiş olduğu için Hitler'in bu taarruzu zaruriydi. Alman ordularının Hollanda, Belçika ve Lüksemburg üzerinden yaptığı bu saldırı, aynı zamanda İngiltere ve Fransa'ya karşı olduğuna göre geçen senenin Eylülü’nden beri Batı Cephesi'nde beklenen büyük taarruz başlamış oluyordu ${ }^{65}$. Bu durum karşısında Almanya'ya karşı tarafsız olmak için Fransa ile askerî bir anlaşma yapmayan ve hatta tehlike başladıktan sonra bile bir savunma planı hazırlama gereği duymayan Belçika, sınırlarını karadan ve havadan Alman askerlerinin aşmasından sonra Paris ve Londra'dan ancak yardım isteyebilmiştir ${ }^{66}$. Tarafsızlık meselesinde Belçika'nın yanıldığını, Şevket Bilgin de düşünmektedir:Gömleğini parçalamış bir zır deli etrafina ne kadar dehşet saçabilirse bu günkü Avrupa'nın küçük bitarafları da hitlerizm karşısında o nispette endişe ve telaş içindedirler. Yakın günlere kadar şu kat'i bîtaraflık kelimesinin belki bir manası vardı. Ona dört elle sarılan memleketler şimdi feci bir şekilde aldandıklarını hissediyorlar ${ }^{67}$.

Falih Rıfkı Atay için ise Hitler'in nerede duracağı merak konusudur: Almanya ne yapıyor. Maksadı Hollanda ve Belçika'yı işgal ederek, büyük düşmanı, Ingiltere'yi yakından tazyik altına almak mıdır? Yoksa kati mukadderat zarın mı atıyor? Bu taarruza Alman milletinin bin senelik istikbalini bağlayan Hitler, Belçika hudutlarında duracak mı? Herkes bu müthiş çı̆̆ın hızını nerede alacağını düşünüyor ${ }^{68}$. Norveç, Belçika ve Hollanda'nın tarafsızlık konusunda gafil avlandığından Falih Rıfkı da emindir: Bir gün istilaya uğrayacaklarından emin olsalardı şüphesiz daha ilk adımda müttefiklerle, hiç olmazsa plan kâğıld üstünde hareket birliğ yaparlardı. Ayrıca Atay, son saldırının arifesine kadar tarafsızlığa sadık kalan bu devletlerin yanıldığı ve 10 Mayıs'ta Belçika'ya yardıma giden Fransız ve İngiliz ordularının bir meçhuller âlemi içine daldığı düşüncesindedir ${ }^{69}$.

Nadir Nadi için heyetin İngiltere'ye geçişi "buhranın başlangıcına" rastlamıştır ve Alman askerî harekâtı önemli bir aşamaya gelmiştir: Almanlar Hollanda'nın istilasını tamamlamışlar, Belçika'da hayli ilerlemişlerdi. Sedan civarında Fransız topraklarına bile girmiş bulunuyorlard $\imath^{70}$. Necmettin Sadak, yolculuğun savaşın en heyecanlı dönemine rastladığını düşünmektedir: Paris'e vardığımız gün Alman orduları Hollanda ve Belçika'ya taarruz etmişti. Belçika kralının teslim olduğunu gelirken yolda öğrendik ${ }^{71}$.

Neticede Hollanda, Belçika ve Lüksemburg'u işgalini takip eden on gün sonunda bu bölgelerdeki askerî harekât Almanya lehine gelişti. Bu süre zarfinda Hollanda ordusu teslim

\footnotetext{
${ }^{64}$ Nadir Nadi, “Amirallik 1. Lordu ve Kuru Yemişlerimiz”, Cumhuriyet, 6 Haziran 1940, s. 3.

${ }^{65}$ Asım Us, “Taarruz Haberi Paris’te Nas1l Duyuldu?", Vakit, 19 May1s 1940, s.1.

${ }^{66}$ Asım Us, "Umumi Vaziyete Bir Bakış", Vakit, 31 Mayıs 1940, s. 1-5.

${ }^{67}$ Şevket Bilgin, "Londra Yolunda", Yeni Asır, 19 Mayıs 1940, s. 1.

${ }^{68}$ Falih Rifk1 Atay, "Taarruz Sabah1", Ulus, 1 Haziran 1940, s. 2.

${ }^{69}$ Falih Rifkı Atay, "Ceb'e Doğru”, Ulus, 2 Haziran 1940, s. 2.

${ }^{70}$ Nadir Nadi, "İngiltere’ye Geçerken", Cumhuriyet, 5 Haziran 1940, s. 5.

${ }^{71}$ Necmettin Sadak, "İki Milleti İçinden Gördük", Akşam, 31 Mayıs 1940, s. 1.
} 
oldu. Fransa'nın savunma cephesi yarıldı. Almanlar Manş sahillerini işgal etti. İngiliz ordularının güneyle bağlantıları kesildi. 26 Mayıs'ta da Belçika kralı teslim oldu².

Alman askerî harekâtının Müttefikler aleyhine geliştiği günlerde İngiltere'de on gün kalan ve İngilizlerin bu günlerde gösterdiği azim ve soğukkanlılığa hayran olan gazeteciler, bu durumu köşelerinde sık sık dile getirdi. Bu doğrultuda Ahmet Şükrü Esmer, garsondan ve mağazacıdan devlet adamına kadar her İngiliz'in ağzında we shall see this thing through yani bu işi muvaffakiyetle neticelendireceğiz parolasının olduğunu yazmaktadır. Ayrıca Esmer, İngilizlerin buna inanmakla kalmayıp iman ettiklerini, hiç bir İngiliz'in Almanlar tarafindan İngiltere'ye yapılacak olan teşebbüslerin bir askerî netice verebileceğine inanmadığını ve İngiliz milletinin kendilerine olan bu güvenini kendi tarihlerinden ve kendi damarlarındaki kandan aldıkları kanaatindedir ${ }^{73}$. Başka bir yazısında İngilizlerin birbirini takip eden bu acı haberler karşısında ümitsizliğe düşmediğini ve savaş içinde birlik manzarası sergilediği düşüncesindedir: Endüstri liderleri her sınıf halk tabakası ve işçiler arasında yaptı̆̆ımız temaslardan da bütün İngiliz milletinin, tarihte bir misline tesadüf edilmeyen tesanütle bugünkü hükümet etrafinda toplandığını anladik ${ }^{74}$.

İngilizlerin birlik ve beraberliği Falih Rıfkı Atay'ın köşesine şöyle yansır: İngiliz adalarında mesuliyet rıhtım üstündeki isçiden Başvekile kadar bütün vatandaşlar arasında paylaşılmıştır... Hiç bir hayale kapılmayan, sonuna kadar harp mukadderatının her türlü seyrini kabul eden, tehlike arttıkça sükûnu, kararı ve iradesi artan bir olgun millet havası ${ }^{75}$ ! Nadir Nadi'ye göre İngiltere, savaş afeti karşısında hızlı çalışmaktadır: Daha iki sene evvel askerlik hizmetini lüzumsuz bir yük sayan bir milletin şimdi ne içten gelen bir hızla silaha sarıldı̆̆ını söylemem herhâlde lazımdi ${ }^{76}$. Necmettin Sadak için bu zor günlerde İngiltere, bir kışla ve talimhaneye dönüşerek insanlarını ülkenin dört bir yanında modern silahlarla eğitmiş ve cepheye sevk etmiştir. Ayrıca İngilizler, fabrikalarında gece gündüz çalışarak savaş malzemesi hazırlamışlar ve er geç savaşı kazanacaklarından emindir: Şu veya bu cephede dünkü yahut yarınki muharebe ile değil ancak Almanya'nın mağlup olacağl yer ve zamanda biteceğini bilmektedir. Sadak'a göre böylesine bir hazırlık İngilizlerin tarihinde hiçbir düşmana karşı yapılmamıştır ${ }^{77}$.

Gazetecilerin Londra'da bulunduğu sırada İtalya henüz savaşa girmemişti. İtalya, Fransa'nın yenilgisine az bir zaman kala 10 Haziran 1940 günü Fransa ve İngiltere'ye savaş ilan edecektir $^{78}$. İtalya'nın savaşa girişi böyleyken, gelişmenin öncesi heyetteki Türk gazetecilerin gündemini meşgul edecektir. Bu konuda Necmettin Sadak, İtalya'nın savaşın bitmesine bir iki ay kala veya barış masasına oturacağına kanaat getirmedikçe savaşa girmeyeceğini düşünmektedir. Çünkü İtalya, fakir bir memlekettir ve denizler kapanınca kendi kendine yetemeyeceği için uzun sürecek bir savaşa giremez. Bununla birlikte İtalya, harbe girmek için evvela Hitler ordularının Fransa'y istila edeceklerine emin olmak istemektedir. Ayrıca Sadak, İtalya'nın Amerika'yı göz ardı etmemesi gerektiğini düşünmekte ve Amerika'yı İtalya'nın savaşa girmesini engelleyen amillerden biri olarak görmektedir. Zira Amerika'nın savaş girmesi Müttefikler için büyük bir kazanç olacağı gibi Kuzey ve Güney Amerika ile hayati derecede ticari ilişkiler içinde bulunan İtalya için felaket olabilir ${ }^{79}$.

\footnotetext{
${ }^{72}$ Ahmet Şükrü Esmer, "Bir Seyahat'in Notları”, Ulus, 4 Haziran 1940, s.3; , Basil Liddel Hart, İkinci Dünya Savaşı Tarihi, Çev. Kerim Bağraçık, İş Bankası Kültür Yay., İstanbul 2015, s. 95-110.

${ }^{73}$ Ahmet Şükrü Esmer, "Bir Seyahat'in Notları", Ulus, 3 Haziran 1940, s.3.

${ }^{74}$ Ahmet Şükrü Esmer, "Bir Seyahat'in Notları", Ulus, 4 Haziran 1940, s.3.

${ }^{75}$ Falih Rifk1 Atay, "Büyük Tehlike Günleri”, Ulus, 3 Haziran 1940, s. 2.

${ }^{76}$ Nadir Nadi, "1000 Senelik Bir Dramın En Feci Dakikaları", Cumhuriyet, 7 Haziran 1940, s.3.

${ }_{77}$ Necmettin Sadak, "İki Milleti İçinden Gördük", Akşam, 31 Mayıs 1940, s. 1.

${ }^{78}$ Koçak, Türkiye'de Milli Şef Dönemi, C.I, s. 302.

${ }^{79}$ Necmettin Sadak, "İtalya Niçin Hala Harbe Girmiyor", Akşam, 3 Haziran 1940, s. 1-5.
} 
Asım Us'a göre İtalya'nın savaşa girmesi mümkün olmakla birlikte girmeme ihtimali de bulunmaktadır. Çünkü Almanya, Fransa ile olduğu kadar İngiltere'yle de savaşmaktadır. Bu nedenle İtalya'nın Fransa'ya saldırması demek kendisini İngiltere ve onun müttefikleri ile de muharip vaziyete düşürmesi demektir. Almanya ile İtalya birleşerek ortak bir saldırı planı takip etseler bile savunmada kalacak olan kuvvetli bir Fransız ordusunu ortadan kaldırmak zor olacaktır. Demir, kömür ve petrol bakımından Almanya'dan zayıf olan İtalya'nın savaşa girmesi demek git gide Almanya'nın tahakkümü altına girmek demektir. Bunlara ilaveten Almanya'nın yanında savaşa girecek bir İtalya'nın Sovyetler Birliği ve Amerika'yı da düşünmesi gerekmektedir: Harbe girmek Italya'nın elinde ise de ondan çımak artık elinde değildir. Harbe iştirak eden İtalya'nın ilk zamanlarda kazancl olsa bile sonradan kaybedecekleri şeyler bu kazançtan çok büyük olacaktır ${ }^{80}$.

Almanya'yı medeniyet ve insanlık düşmanı olarak gören Şevket Bilgin için İtalya'da üç büyük kuvvet vardır ve bunlar arasında da savaşa katılıp katılmama konusunda görüş birliği yoktur: Vatikan, saltanat kuvvetleri ve müfrit faşistler arasında bariz düşünce ayrılıkları mevcuttur. Mussolini, hanedana ve Vatikan'a arkasını çevirerek harbe mi girecek yoksa hakikaten realist bir politika takip ederek medeniyet ve insanlık düşmanı olan Almanya ile teşrik-i mesainin imkânsızlı̆̆ını teslim mi edecek? ${ }^{81}$. Bütün bu yaşananlar ve izlenimlerin ardından İngiltere temaslarını tamamlayan heyet, 30 Mayıs 1940 günü Türkiye’ye döndü ${ }^{82}$.

\section{4- 1942 Berlin Gezisi}

Müttefiklere karşı 1942'de güç kazanan Almanya, doğu cephesindeki askerî başarılarını ispat etmek ve tamamen propaganda amacıyla, Türk basın heyetini üç haftalık bir gezide doğu cephesini gezdirmek üzere ülkesine davet etti ${ }^{83}$. Çünkü Türkiye'yi siyasi olarak etki altına almak isteyen Almanya'nın propaganda metotlarının başında kitle iletişim araçları ve basın gelmekteydi ${ }^{84}$. Heyet, tamamı Almanya lehine yazılar yazan gazeteciler Akşam başyazarı Necmettin Sadak, Vakit başyazarı Asım Us, Cumhuriyet başyazarlarından Nadir Nadi, Türk Sözü sahibi Nevzat Güven ile Matbuat Umum Müdürü Selim Sarper'den oluşmaktayd ${ }^{85}$.

Geziye katılanlar arasında en dikkat çekici olanı o sırada askerlik görevini yapmakta olan Nadir Nadi'dir. Gezide politik görev verilen ve bundan oldukça gururlanan Nadi, bu durumu anılarında şöyle aktarmaktadır: Alman Hükümeti, bir Türk basın heyetini ve ayrıca Basın-Yayın Umum Müdürünü, üç haftalık bir gezi için resmen Almanya'ya davet etmişti. Bu heyete benim de katılmamı uygun bulan Hükümet harekete geçmiş, Dışişleri, Milli Savunma Bakanlıkları ve Genelkurmay Başkanlığı arasındaki yazışmalar sonucu olarak bana bir aylık bir 'mezuniyet' sağlanmıştl. Doğrusu bu bir mezuniyetten ziyade politik bir göreve benziyordu. Gidecektim, görecektim ve dönüşte izlenimlerimi de yazacaktım. Cumhuriyet tarihi boyunca, yedek subaylığını yaptığı sırada böylesine ayrıcalıklı bir işleme uğrayan başka bir gazeteci bulunabileceğini sanmıyorum. Babıâli'de, Almanya'ya gönderilebilecek düzinelerle gazeteci

\footnotetext{
${ }^{80}$ Asım Us, “İtalya Harbe Girecek mi?”, Vakit, 1 Haziran 1940, s. 1-4.

${ }^{81}$ Şevket Bilgin, "Londra yolunda", Yeni Astr, 19 Mayıs 1940, s. 2.

${ }^{82}$ Us, Hatıra Notları, s. 383-396; Asım Us, "Umumi Vaziyete Bir Bakış", Vakit, 31 Mayıs 1940, s.1.

${ }^{83}$ Koçak, Türkiye’de Millî Şef Dönemi, C.I, s. 646; Aydoğmuş, İkinci Dünya Savaşı Sürecinde Propaganda ve Türkiye, s. 177.

${ }^{84}$ Johannes Glasneck, "Alman Faşizminin Türkiye'deki Propaganda Faaliyetleri”, Çev. Murat Çakır, 1966 yılında Halle'deki Martin-Luther-Üniversitesi'nin “Wissenschaftliche Beiträge" adlı dizininde yayınlamıştır, s. 4.

${ }^{85}$ Vakit, 17 Temmuz 1942, s.1; Kızılca, "1942 Yılında Mihver ve Müttefik Devletlerce...”, s. 11; Koçak, Türkiye’de Millî ŞefDönemi, C.I, s. 646-647.
} 
dururken, benim askerlikten alınıp bu işe seçilmemi kişiliğimin Hükümet gözündeki önemine yordum, doğrusu göğsüm kabardl ${ }^{86}$.

Almanya, Türk basınını etkilemek için bazı gazete sahiplerine ve gazetecilere rüşvet vermişti. Alman Dışişleri Bakanı Ribbentrop, 9 Mart 1941'de Türkiye'nin Almanya sefiri Von Papan'e bir telgraf göndererek “Türkiye'nin tarafsızlığını sağlayabilmek" amacıyla Türk basın ve radyo çalışanlarına birkaç milyon liranın döviz olarak dağıtılmasını istedi. Von Papen cevap mektubunda bu işlemin başarıyla tamamlandığını bildirdi. Türk basınından Alman saldırısına uğrayan komşu ülkelere karşı kayıtsız kalınması isteniyordu ${ }^{87}$. Hükümet ve İsmet İnönü Almanlardan para aldığını düşündükleri Nadi'nin Almanya lehine yazılar yazacağına kesin gözüyle baktıkları için askerliğini yapıyor olmasına rağmen onu da geziye dâhil etmişlerdi. Geziye Almanya'ya yakın gazetecilerin gönderilmesi bu ülkeye karşı yürütülen politikanın bir sonucu olarak değerlendirilebilir ${ }^{88}$.

Von Papen, 17 Temmuz 1942 günü Tarabya'daki sefarethanede Almanya'ya gidecek gazetecilere bir öğle yemeği verdi. Yemekte gezinin ana çerçevesi kararlaştırıldı. Berlin'de birkaç gün kalınacak sonra Batı Almanya ve işgal altındaki Fransa'nın bir kısmı dolaşılacak, Münih'ten Viyana'ya oradan da Doğu Cephesine gidilecekti. Gezi bitiminde grup Peşte'ye bırakılacak, İstanbul'a dönmeden önce Sofya'da ikişer gün Macar ve Bulgar hükümetlerinin misafiri olacaklard1 ${ }^{89} .16$ Temmuzda yola çıkan grup 20 Temmuz günü Berlin'e ulaşt1 ${ }^{90}$.

22 Temmuz 1942'de Ulus'ta yayımlanan bir yazı Almanların Türk gazetecilerinden ne beklediğini ortaya koyması bakımından önemlidir. Yazıda Alman Matbuat Müdürü Dr. Dietrich şunları söylediği aktarılmaktadır: Alman milleti Türk milletine dostlukla bağlıdır. Müşterek mücadelenin çetin yılları hatırası iki milletin hâlinde yaşamakta olduğu gibi her ikisinin de içerde düzelerek yeniden kalkınmak için kuvvet bulmuş olmalarından doğan gurur ve iftiharla yaşamaktadır... Basın iki milletin hür düşüncelerinin tercümanıdır. Alman basını bu vazifeyi şimdiye kadar idrakli bir suretle yapmış daima alman milletine Türk milletini olduğu gibi göstermeye çalışmıştır. Türk basınının da Almanlar hakkında aynı niyetleri beslediğini düşünen Dr. Dietrich'e karşı heyet başkanı Necmettin Sadak bu beklentiye uygun şekilde şu cevabı vermiştir: Bu ziyarette büyük bir milletin gösterdiği gayretler hakkında bir fikir edinmeyi en asil bir vazife olarak telakki etmektedir. Şimdi olduğu gibi hiçbir zaman düşman olarak karşı karşılya geçmemiş olan Alman ve Türk milletlerini bir dostluk bağ birleştirmektedir. ... Bu nevi ziyaretlerin birbirimizi karşılıklı olarak daha iyi tanımamıza ve milletlerimizin daha ziyade yaklaşmasına hizmet edeceğine şüphem yoktur ${ }^{91}$.

Türk hükümetinin heyetten beklentisi ise somut durum hakkında bilgi veren haberlerden ziyade hükümetin birer temsilcisi gibi ilişkilerde bulunmak, Müttefiklere karşı denge politikasının gereği olarak da Türk kamuoyunda rahatsızlık yaratmamak kaydıyla Mihver devletleri lehine haberler aktarmalarıyd $1^{92}$.

Heyet Berlin'de Alman Propaganda Bakanı Goebbels ile bir görüşme yaptı. Nadir Nadi'ye göre Goebbels, sorulardan kaçınmakta ve kendilerine soru sorma firsatı bile vermemektedir: Dr. Göbbels'le bir saate yakın konuştuk. Daha doğrusu o konuştu, biz dinledik. Oldukça

\footnotetext{
${ }^{86}$ Nadi, Perde Aralı̆̆ından, s. 183.

${ }^{87}$ Glasneck , “Alman Faşizminin Türkiye'deki Propaganda Faaliyetleri”, s. 6.

${ }^{88}$ Kızılca, "1942 Yilında Mihver ve Müttefik Devletlerce...,", s.12.

${ }^{89}$ Nadi, Perde Aralığından, s.184; Us, Hatıra Notlarl, s. 469.

${ }^{90}$ Cumhuriyet, 17 Temmuz 1942, s.1; Akşam, 17 Temmuz 1942, s.1; Us, Hatıra Notları, s. 471;

Kızılca, "1942 Y1lında Mihver ve Müttefik Devletlerce...", s. 12.

${ }^{91}$ Ulus, "Türk Matbuat Heyeti Berlin'de", 22 Temmuz 1942, s. 1-2.

${ }^{92}$ Kızılca, "1942 Yılında Mihver ve Müttefik Devletlerce...", s.13.
} 
musikili, tatlı bir sesi vardı. Bağırmıyor, heyecana kapılmıyor, fakat cümlelerin önemine göre sözcüklerin ve hecelerin ahengini tam yerinde idare etmesini biliyordu. Sorulardan kaçındı $\breve{g} l$ belli idi. Acele etmemekle beraber, nutuk söyler gibi, sözünün kesilmesine imkân vermeksizin konuşuyordu $u^{93}$. Nadi'nin bu izlemine karşı Nevzad Güven, Goebbels'e hayranlığını gizleyemez: Karşımızda hakiki bir centilmen zevki ile giyinmiş, kibar, çok sevimli, zeki ye parlak gözleri ile insanın içine bakan bir adam duruyordu... Elli dakika durmadan konuştu ve ben bir tek kelime Almanca anlamadı̆̆ım hâlde onu zevkle dinledim ${ }^{94}$.

Berlin'de tank mektebini ziyaret eden gazeteciler, daha sonra çelik fabrikasına gitmiş ve sonra da Kassel, Frankfurt, Wiesbaden ve Lüksemburg'u gezmişlerdir. Lüksemburg gezisi sonrası heyet, Fransa'ya giderek Majino (Maginot) hattına geçmişlerdir ${ }^{95}$. Gazeteciler bu geziden edindikleri intibalar neticesinde Alman ekonomisinden övgüyü hak edecek şsekilde etkilenmişlerdi. Örneğin, bir taraftan esnafin vurgunculuğunu önlemek için çok şiddetli tedbirler alındı̆̆ hâlde diğer taraftan halkın zaruri ihtiyaç dışında mal almaması için de her türlü giyecek eşyasının satışı tahdit edilmiştir diyen Asım Us, Almanya'yı neredeyse baştan sona gezdikleri hâlde eski püskü kıyafetli hiç kimseye rastlamadıklarını ve halk arasında fizyolojik sefaleti hissettiren hiçbir emare görmediklerini belirtir. Yazısının devamında Almanya'nın harbe uzun yıllar dayanacağı kanaatindedir: Almanya'nın harp mahrumiyetlerinin tesiri altında öyle bir kaç senede çökeceğini farz edenler aldanırlar. Almanya'da harbin bu sene biteceği yolunda ümit besleyen hiçbir muhit yoktur. Ayrıca Us'a göre Almanlar, bir barış projesi düşünmektedir ve bu projeyle kendi kendine yeter bir Avrupa düzeni kurmak istemektedir: Almanlara göre bu tarzda bir sulh Ingiltere ve Amerika harpten usanincaya kadar Avrupa milletlerinin normal hayatı olacaktı ${ }^{96}$.

Nadir Nadi için Almanya'da büyük bir açlık ve sefalet hüküm sürdüğü gibi bilgiler sadece bir propaganda faaliyetidir ve gerçeği yansıtmamaktadır: Glda bahsinde bazı maddelerde darlık çekildiği doğrudur. Mesela şeker yalnız çocuklara ve hastalara ayrlmıştır. Süt ve tereyağı az verilmektedir. Buna mukabil patates ve lahana gibi sebzeler vesikasız satıllyor. Gittigim yerlerde mariz ve hasta yüzlü insanlara rastladı̆̆ımı hatırlamıyorum. Bütün Almanya'da bir tek dilenci görmediğimi iddia edebilirim ${ }^{97}$. Necmettin Sadak'1n değerlendirmeleri daha gerçekçidir: Topyekûn denilen harbin ne biçim bir savaş olduğunu bu seferki seyahatimizde Almanya'da gördüm. Sadak'1n edindiği izlenimlerde, topyekûn savaşta seferberlik ve cephe yoktur ve bütün memleket mekanizması sadece savaş uğruna işlemektedir. Ayrıca Sadak'a göre Almanya'da savaş için çalışmayan ve çarpışmayan bir tek fert yoktur ve savaşta genç, ihtiyar, kadın, erkek her vatandaşa bir görev yüklenmiştir. Kısaca Almanlar savaştan dolayı çok sıkıntı çekmekle birlikte, Almanya'da halkın genelinin bu sıkıntı ve acılara katlanması sayesinde böylesi bir felaketten hızlıca kurtulmak tek çaredir ${ }^{98}$.

Nevzad Güven için Almanya'da ilk göze çarpan şey, ülkenin bütün varlık ve imkânları ile seferber olduğu ve savaşı kazanmak için insanüstü bir çaba gösterildiğidir: Bütün Almanya kadını, erkeği, genci, çocuğu ile savaşa girmiştir. Her Almanın gündelik çalışmasında bir harp gayreti vardır. Güven, savaşı kazanmaktan başka yol olmadığı fikrinin her Alman'ın kafasına

\footnotetext{
93 Nadi, Perde Aralı̆̆ından, s. 190-191; Nadir Nadi, “Göbbels’le Bir Saat”,Cumhuriyet, 21 Ağustos, 1942, s. 1-3.

${ }^{94}$ Nevzad Güven, “Alman Propaganda Nazırı İle Görüşme”, Türk Sözü, 22 Ağustos 1942, s.1.

${ }^{9}$ Us, Hatıra Notları, s. 472-474; Nevzad Güven, "Ren'de Bir Dolaşma”, Türk Sözü, 2 Eylül 1942, s.1; Asım Us, “Zigfrid Hattından Nasıl Geçtik?”, Vakit, 13 Eylül 1942, s. 1; Nadir Nadi, "505 Sayılı Korugan”, Cumhuriyet, 27 Ağustos 1942, s. 3.

${ }_{96}$ Asım Us, "Almanya Disiplin Memleketi”, Vakit, 22 Ağustos 1942, s. 1-2.

${ }^{97}$ Nadir Nadi, "Berlin'de Hayatın Manzarası”, Cumhuriyet, 19 Ağustos 1942, s. 1-3.

${ }^{98}$ Necmettin Sadak, “Topyekûn Harbin Ne Demek Olduğunu Almanya'da Gördüm”, Akşam, 19 Ağustos 1942, s. 1.
} 
iyice yerleştiğini ve bunun için de belirlenen parolayı köşesine yansıtır: Harbi mutlaka kazanmak lazımdır. Bunun için de parola şudur: Herkes ve her şey ordu için ...99

16 Ağustos’ta ${ }^{100}$ yurda dönen gazeteciler, her firsatta Türk-Alman dostluğundan bahsederek gezi süresince Almanya'da gördükleri ilgiyi köşelerine taşımış ve açık bir şekilde Alman propagandası yapmışlardır. 1930'lu yıllardan itibaren Birinci Dünya Savaşı'ndaki silah kardeşliğini sürekli ön plana çıkaran ${ }^{101}$ ve bunu bir propaganda aracı olarak kullanan Almanya'nın amacına ulaştığını söylemek mümkündür. Bu yönde Asım Us, Türklerle Almanların tarihte hiç bir zaman silahla karşılaşmadığınıve Münih'te "Türkenstrasse" yani "Türk Caddesi" adında bir cadde, Türk ismi ile anılan Alman aileleri ve civarda Türk ismi taşıyan köyler olduğunu belirterek ${ }^{102}$ savaş döneminde Alman imajına katkı sunmuştur. Nadir Nadi, günlerce süren temaslarımız esnasında etrafimızı kaplayan samimi ve sicak dostluk havasının bizde bıraktı̆̆ güzel duyguları kelime ve cümle kalıpları içine siğdıramayacağıma eminim $^{103}$ diyerek Türk hükümetin kendisinden beklentisini yerine getireceğinin ipuçlarını vermektedir. Her ne kadar anılarında objektif olmaya çalıștığın $1^{104}$ belirtse de bunda pek de başarılı olduğu söylenemez. Necmettin Sadak gezide kendilerine gösterilen ilgiden fazlasiyla memnundur: Bütün bu yolculuktan üzerimizde kalan ve hemen yazmayl vazife bildiği ilk tesir bize gösterilen büyü̈k dostluk, her tarafta karşılaştığımız tarifi güç izzet ve ikramdır. Bunun yanında zorlu bir savaşın ortasında kendilerini hiçbir sıkıntı hissettirmeden gezdiren Alman hükümetine ve yetkililere teşekkür etmiş ve bu müstesna kabulü gazetecilik vasıflarından ziyade Türk vatandaşlı̆g s şerefine borçlu olduklarını belirtmiştir ${ }^{105}$. Ayrıca Sadak, dost Almanya'da tahminlerin üstünde bir hüsnükabul gördüklerini ve Almanya'nın normal hayatına devam ettiğini okuyucularına aktarmıştır ${ }^{106}$.Nevzad Güven de Sadak ile aynı düşünceleri paylaşmaktadır: Hiç şüphe yok ki bütün bu seyahat esnasında bize karşı gösterilen nezaket ve ihtimamı, şahıslarımızdan, ziyade dostlarımızın Türk milletine karşı duydukları büyük alakanın bir tezahürü olarak görmek lazımdır. Geçtikleri her yerde politika gereklerinin dışında bir sevgi tezahürü ile karşılaştıklarını ve gezi hakkındaki görüşlerini en objektif şekilde okuyucularla paylaşacağını ifade etmektedir ${ }^{107}$.

Asım Us, Almanya dönüşünde bu geziden edindiği intibaları bir rapor hâlinde Başbakan Şükrü Saraçoğlu'na sundu. Dikkat çekici bu rapora göre Almanya yeni bir Avrupa nizamı kurmaya çalışmaktaydı ve Almanlar kendi kendine yeten bir Avrupa haritası içine Türkleri de koymuştu ${ }^{108}$. Us'un raporu, İkinci Dünya Savaşı'yla dünyada egemenlik kuracağı düşünen Alman faşizminin, Türkiye politikasının temel amacını ifade ettiği NSDAP (Nasyonal Sosyalist Alman İşçi Partisi) Basın Bürosunun 19 Kasım 1941 tarihli bildirisinde yer alan “Avrupa'nın yeni düzeni içerisinde, Türkiye de dâhil olmak üzere tüm Avrupa ülkeleri yerlerini alacağı" hedefiyle de örtüşmektedir ${ }^{109}$. Görülen o ki Türk heyeti, kendilerinden beklenen şekilde, savaşın en yoğun atmosferi içerisinde yaptıkları bu gezideki Alman propagandasından etkilenmişler ve izlenim olarak da bunları köşelerine yansıtmışlardır.

\footnotetext{
${ }^{99}$ Nevzad Güven, “Almanya'daki Hayat”, Türk Sözü, 27 Ağustos 1942, s.1-3.

${ }^{100}$ Faruk Fenik, “Gazetecilerimiz Almanya'dan Döndüler”, Vatan, 17 Ağustos 1942, s.1-3; Vakit, 16 Ağustos 1942, s.1; Tan, 17 Ağustos 1942, s.2.

${ }^{101}$ Glasneck, "Alman Faşizminin Türkiye'deki Propaganda Faaliyetleri”, s.3.

102 Asim Us, "Münih’te Türk Caddesi”, Vakit, 1 Ekim 1942, s. 1.

${ }^{103}$ Nadir Nadi, "Alman Ordusunda Yeni Ruh Ve Yeni Savaş Birlikleri”, Cumhuriyet, 23 Ağustos 1942, s. 1.

${ }^{104}$ Nadi, Perde Aralığından, s. 220.

${ }^{105}$ Necmettin Sadak, "Harp Ortasında Bir Aylık Yolculuktan Dönüş", Akşam, 17 Ağustos 1942, s. 1.

${ }^{106}$ Fenik, "Gazetecilerimiz Almanya'dan Döndüler", s.3.

${ }^{107}$ Nevzad Güven, "Savaştaki Almanya”, Türk Sözü, 21 Ağustos 1942, s.1.

${ }^{108}$ Us, Hatıra Notlarl, s. 483-490.

${ }^{109}$ Glasneck , “Alman Faşizminin Türkiye'deki Propaganda Faaliyetleri”, s.3.
} 
İkinci Dünya Savaşı'nda Türk Gazetecilerin Londra ve Berlin Gezileri ve İzlenimleri (1939-1942)

\section{5- 1942 Londra Gezisi}

Almanya'nın düzenlediği basın gezisine karşı İngiltere ve Amerika da bir Türk basın heyetini kendi kontrollerindeki bölgeleri gezdirmek amacıyla ülkelerine davet etti ${ }^{110}$. İngiltere'nin davetinde 1942 y1lında İngiltere'ye büyükelçi olarak atanan Rauf Orbay ${ }^{111}$ ' 1 ' önemli katkısı vardır. Büyükelçi, gazetecilerin Almanya'ya yaptıkları gezinin İngiltere'de olumsuz bir hava yarattığını fark etti. Orbay, bu durumun Türk-İngiliz ilişkilerinde bir soruna dönüşmesini önlemek amaciyla Ankara'dan, bir grup gazeteciyi Londra'da temaslarda bulunmak ve İngiltere'nin savaş sanayi merkezlerini gezmek maksadiyla İngiltere'ye gönderilmesini istedi. Fakat Ankara bu daveti İngiltere'nin yapmasının daha uygun olacağını belirtmesi üzerine Orbay, İngiliz Dışş̧leri Bakanı Antony Eden ve İstihbarat Bakanı Brenda Bracken ile görüşerek bu davetin yapılmasını sağladı. Heyet İngiltere'den sonra Amerika'ya giderek temaslarına devam edecekti ${ }^{112}$.

Ahmet Emin Yalman'a göre Türkiye'nin Müttefiklerin zaferine inanmasına ve onların davasına samimi bir şekilde bağlanmasına Batı'da büyük önem verildiği için gazeteciler Batı'ya çağırılmıştır ${ }^{113}$. Bunların yanında Almanya'ya gönderilen heyetle bir denge kurmak ${ }^{114}$ için yapılan bu gezide üzerinde durulması gereken bir nokta önemlidir. O da Türkiye'nin geziye katılacaklara daveti isim belirtilmeden yapılmasını istemesidir. Böylelikle geziye gidecek gazetecileri Türk hükümeti seçmiştir. Zira Almanya gezisine katılacak gazetecilerin kimlerden oluşacağını Almanlar belirlemişti ${ }^{115}$.

Heyette Ulus gazetesinden Ahmet Şükrü Esmer, Tan gazetesinden Zekeriya Sertel, Yeni Sabah gazetesinden Hüseyin Cahid Yalçın, Vatan gazetesinden Ahmet Emin Yalman ve İkdam gazetesinden Abidin Daver ${ }^{116}$ bulunmaktaydı. Heyet üyelerinin hepsi de Müttefik yanlısı yazarlardan oluşmaktayd1 ${ }^{117}$.

Heyetin başkanı İngiliz sempatizanı Hüseyin Cahid Yalçın'dı. İngiliz Dışişleri belgelerinde geçen "hepsi az ya da çok İngiliz taraftarıdır" ifadesi bu sempatiyi destekler niteliktedir. Amerikan Dışişleri Arşivinde yer alan belgelerde Sertel hariç geziye katılan tüm gazeteciler için olumlu görüşler yer almaktadır. Burada; Ahmet Şükrü Esmer "azimli ve dengeli bir yazar", Ahmet Emin Yalman “yetenekli”, Hüseyin Cahid Yalçın "belki de Türkiye’nin en ünlü yazarı” şeklinde tanımlanmıştır. Abidin Daver’e yorum yapılmamış, Zekeriya Sertel ise "liberal ya da Türk liberallerinin lideri olarak tanımlanmaması gerektiği ve yabancı düşmanı" ve "muhalif"

\footnotetext{
${ }^{110}$ Kızılca, “1942 Yılında Mihver ve Müttefik Devletlerce...”, s.16.

111 Rauf Bey'in büyükelçiliği Ahmet Emin Yalman'a göre Türkiye-İngiliz ilişkilerini geliştirmesi bakımından önemlidir: Rauf Orbay'ın sefir sıfattyla Londra'da yarattı̆g hava Ingiltere'de ve bütün hür dünyada nüfuz ve itibarımızı yükseltmişti... Orbay'ın seciyesi, dürüstlüğü, lisana hâkim olması, İngiliz ruhunu bilmesi, fikrini icabında da en sert şekilde söylemekten çekinmemesi sayesinde elde ettiği mevki, bir sefirin mevkiinden çok fazla olmuştur. Ahmet Emin Yalman, Yakın Tarihte Gördüklerim ve Geçirdiklerim, C. II, Yay. Haz. Erol Şadi Erdinç, İstanbul 1997, s. 1164-1172.

${ }^{112}$ Nur Özmel Akın, “1942 Yllında Türk Gazetecilerin İngiltere Gezisi”, Tarih ve Toplum, S. 189, s. 132-133.

${ }^{113}$ Yalman, Gördüklerim ve Geçirdiklerim, C. II, s. 1164.

${ }^{114}$ Koçak, Türkiye'de Milli Şef Dönemi, C.I, s. 710.

115 Kızılca, "1942 Yılında Mihver ve Müttefik Devletlerce...", s.17; Akın, "1942 Yılında Türk Gazetecilerin İngiltere Gezisi", s. 133.

${ }^{116}$ Basın tarihi açısından dikkat çeken bir örnek olarak Daver'in bu dönemde hem İkdam hem de Cumhuriyet'te yazıları bulunmaktadır. Cumhuriyet, 9 Şubat 1954, s.7; Milliyet, 9 Şubat 1954, s. 7; Murat Yümlü, "Yarım Asra Ulaşan Basın Emeği Işı̆̆ında Gazeteci Abidin Daver”, Türkiyat Mecmuası Journal of Turkology, c. 29/1, 2019, s.268. 249-299.

${ }^{117}$ Sertel, Hatırladıklarım, s. 200; Koçak, Türkiye'de Milli Şef Dönemi, C.I, 709.
} 
olarak tanımlanmıştır. Buna rağmen Sertel, Almanya karşıtı yazıları dolayısıyla Türk hükümeti tarafından tercih edilmiştir. ${ }^{118}$.

Daver, gezinin amacını belirttiği ilk günkü yazısında tarafsız olacaklarından emindir: Gazetecinin vazifesi masa başında doğru yanlış tahminler yapmaktan Boğazın mavi sularını seyrederek, mütalaa yürütmekten ibaret değildir. Gazeteci her şeyi olduğu gibi harbi de yakından takip ve tetkik ederek muharip milletlerin gayretlerini yakından görerek, müşahedelerini ve intibalarını okuyucularına bir fotoğraf sadakatiyle bildirmekle mükelleftir ${ }^{119}$.

Bu düşüncelerle 21 Ağustos'ta Türkiye'den hareket eden heyet, Londra'ya ${ }^{120} 1$ Eylül'de varmış ve törenle karş1lanmıştır. Times'a bakılırsa gazetecilerin bu ziyareti son derece önemlidir: Misafirlerin hepsi Anglo-Saksonlartn liberal ve demokrat fikirlerine sempati göstermişlerdir. Bu siralarda misafirlerin buraya gelmesi bilhassa klymet ifade eder. Türk gazetecileri karşılayan İngiliz İstihbarat Nazırlı̆gı yetkilisi, Türk basınını mükemmel şekilde temsil eden gazetecilerin, Almanya' ya yapılan ziyarette olduğu gibi, İngiltere için de doğru gözlemlerde bulunacağını düşünmektedir ${ }^{121}$. Yine Times'da Türk gazetecilerin Mihver tarafından aldatılmalarının mümkün olmadığı ve gördüklerini gayet doğru şekilde neşredecekleribelirtilmiştir. Yazının devamında tam bir serbestlik içinde ve bilgi toplamak amacıyla seyahate çıkmış olan gazetecilerin düşünce ve yorumlarının ciddi bir şekilde dikkate alınması gerektiği ifade edilmektedir ${ }^{122}$. Özetle gezinin amaçları doğrultusunda Türk gazetecilerinin edinecekleri izlenimler hakkında önemli bir beklenti söz konusudur.

Gazetecilerin İngiltere programı, Ahmet Emin Yalman'ın da dediği gibi, çok yoğun geçti. Heyet İngiltere'de British Council, Reuter Kingdom Ticaret Teşkilatı, İngiliz Radyo Şirketi, Reuter Ajansı ve İngiliz Basın mensuplarıyla ayrı ayrı toplantılar yapt ${ }^{123}$. Hava saldırılarının neden olduğu tahribat ${ }^{124}$ yerinde gören ve bundan etkilenen halk ile görüşen gazeteciler, İngiliz savaş sanayi tesislerini de gezdiler. Yaklaşık üç hafta süren gezi boyunca Başbakan Churchill, Dışişleri Bakanı Antony Eden ve diğer bakanlarla tanışıp görüşmüşlerdir ${ }^{125}$. Gezi sırasında gazetecileri en çok memnun eden bu görüşmeler, Türk kamuoyunda geniş yer bulmuştur. ${ }^{126}$.

Temaslarda Yalman'ın Churchill'den etkilendiği açıktır: $O$, insan şeklini almış bir milli kuvvettir. Yaşl yoktur, ebedi gençtir. Gözlerinde röntgen taşır. Insanların, hadiselerin içyüzünü görür, her şeyi kolaylıkla tarihi ölçülere vurur. Ayrıca Yalman, Türklerin davasını anlamış ve bu nedenle de kendilerine candan cevaplar verdiğini düşündüğü Churchill'i kendisinden son derece emin olarak görür: Karşımızda her şeyi göze alan, hesaplayan, zorlukları bilen fakat bunların hakkindan geleceğine emin olan bir adam gördük ${ }^{127}$. Ahmet Şükrü Esmer, kendisinde çok enerjik ve azim, irade sahibi bir adamın tavrı vardı dediği Churchill'in Türk-İngiliz ilişkilerinden samimi bir şekilde bahsettiğini belirtmektedir. Churchill'de büyük bir milleti

\footnotetext{
${ }^{118}$ Kızılca, “1942 Y1lında Mihver ve Müttefik Devletlerce...,", s. 18.

${ }_{119}$ Abidin Daver, “Anglo-Sakson Âlemine Doğru”, İkdam, 21 Ağustos 1942, s. 3.

${ }^{120}$ Sertel anılarında yolculukla alakalı olarak, O vakitler bütün yollar kapalıydı. Londra'ya gidebilmek için Suriye ve Kahire yoluyla önce Afrika'ya indik. Sonra Afrika'yı ortasından aşarak Nijerya kıyılarına, Lagos şehrine vardık. Oradan Batı Afrika'yı dolaşarak Portekiz'e çıktık, Londra'ya ancak 15 gün sonra varabildik demektedir. Sertel, Hatırladıklarım, s. 201.

${ }^{121}$ Vatan, 3 Eylül 1942, s. 1-3; Ikdam, 3 Eylül 1942, s. 1-3; Ulus, 3 Eylül 1942, s.1; Akın, "1942 Yllında Türk Gazetecilerin İngiltere Gezisi", s. 133.

${ }^{122}$ Vatan, 4 Eylül 1942, s. 1-3; Tan, 4 Eylül 1942, s. 2.

${ }^{123}$ Yalman, Gördüklerim, Geçirdiklerim, C. II, s. 1173; Vatan, 7 Eylül 1942, s.1-3.

124 İkdam, 6 Eylül 1942, s. 1-3; Vatan, 5 Eylül 1942, s. 1-3; Tan, 5 Eylül 1942, s. 2.

${ }^{125}$ Akın, "1942 Yllında Türk Gazetecilerin Ingiltere Gezisi", s. 133; Sertel, Hatırladıklarım, s.201-202.

${ }^{126}$ Kızılca, "1942 Yllında Mihver ve Müttefik Devletlerce...", s. 23.

${ }^{127}$ Ahmet Emin Yalman, "Çörçil 'le Görüşürken”, Vatan, 14 Eylül 1942, s. 1-3.
} 
etrafında toplayan büyük bir adamın kuvvet ve cazibesi olduğunu söyleyen Esmer, İngiliz Başbakanı'nın Türk politikasının dürüstlüğünü övdüğünü ${ }^{128}$ ve İngiltere'min de "sonuna kadar dövüşün sembolü" olduğu görüşündedir ${ }^{129}$. Bununla birlikte ona göre İngiltere tarihinde Başvekillik sandalyesine bu derece kuvvetle yerleşmiş başka bir devlet adamı bulmak mümkün değildir ve herkes onun yerinin doldurulamayacağına inanmaktadır ${ }^{130}$.

Hüseyin Cahid Yalçın'ı da İngiltere temasları sırasında en çok etkileyen olay Churchill ile yapılan görüşmedir. Yalçın, Churchill'in savaşı kazanmak hususunda beliren millî iradenin temeli ve kudretli vasıtası olduğunu düşünmektedir ${ }^{131}$. Bunun yanında Churchill'in lider özelliklerinden etkilendiği açıktır: Onda senelerin yıpratamadı̆̆ berrak ve taze bir müfekkere ve her şeyin derinliğine işleyen ve bir iki kelime içinde bütün dünya vaziyetini izaha kâfi gelen bir zekâ ile beraber bir azim ve irade parlıyor. Churchill günün adamıdır, günün adamı olarak kalacaktır ve buna laylktır ${ }^{132}$. Zekeriya Sertel de milli birliğin ve harp azminin en büyük amillerinden birini de hiç şüphe yok Churchill'in yüksek şahsiyetinde aramak lazımdır dediği Churchill'i daha da ileri götürerek liderler arasında müstesna bir yere koymuştur: Yorulmak ve yılmak bilmeyen metaneti, en tehlikeli badirelerden muvaffakiyetle çıkmayı bilmesi ve bilhassa azim ve iradesindeki kuvveti ile İngiliz milli birliğinin sembolü ve müstesna devlet adamlarından biri ${ }^{133}$.

Gazeteciler, Churchill'den başka Hizmet Bakanı Ernest Bevin ${ }^{134}$, İaşe Bakanı Lord Woolton $^{135}$, Dâhiliye ve Milli Emniyet Bakan1 Morrison, İstihsal Bakan1 Lytteiton ${ }^{136}$, İstihbarat Bakanı Brendan Bracken ${ }^{137}$ ve Dışişleri Bakanı Antony Eden ile görüştü. Yalman köşesinde, Eden ile samimi bir hava içinde Türk-İngiliz ilişkilerinden, olayların gidişatından ve gelecekten bahsettiklerini yazmıştır ${ }^{138}$. Ahmet Şükrü Esmer ise görüşmenin çok samimi bir şekilde yapıldığını ve Eden'in Türkiye'nin takip ettiği dürüst politikadan coşkunlukla bahsettiğini belirtmektedir $^{139}$. Hüseyin Cahid Yalçın, Eden'le savaş ve savaş sonrası meseleler hakkına görüştüklerini ve Bakanın, sordukları hiçbir soruyu cevapsız bırakmadığını yazmaktadır ${ }^{140}$. Eden'in kendilerini büyük bir samimiyetle kabul ettiğini belirten Zekeriya Sertel de benzer bilgileri aktarır: Kendisiyle yarım saatten fazla konuştuk. Bize maziden, hâlden ve istikbalden bahsetti. Türk-İngiliz dostluğu ve ittifakı üzerinde ehemmiyetle durdu ${ }^{141}$. Abidin Daver, Eden ile resmi değil samimi ve dostça bir görüşme yaptıklarını, bu görüşmenin de Türk-İngiliz dostluğunun teyidi olduğunu, Eden'in kendilerini "aydınlatma" nezaketinde bulunduğunu belirtmektedir ${ }^{142}$.

Gazeteciler gezi boyunca İngiltere'yi savaşın farklı boyutlarıyla övgüye değer bulmuşlardır. $\mathrm{Bu}$ yönüyle öne çıkan yazılarını da gazetelerine göndererek Türk kamuoyunu etkilemeye

\footnotetext{
${ }^{128}$ Ahmet Şükrü Esmer, “Mr. Çörçil’le Türk Gazetecilerin Bir Görüşmesi”, Ulus, 15 Eylül 1942, s. 3.

${ }^{129}$ Ahmet Şükrü Esmer, "Bombalar Altındaki Londra'da", Ulus, 13 İlkkânun (Aralık) 1942, s.2.

${ }^{130}$ Ahmet Şükrü Esmer, “İngiltere'de İç Politika Durumu”, Ulus, 18 İlkkânun (Aralık) 1942, s. 2.

${ }^{131}$ Ulus, 19 Eylül 1942, s.4.

${ }^{132}$ Hüseyin Cahid Yalçın, “Çörçil’le Mülakat”, Yeni Sabah, 16 Eylül 1942, s.1.

${ }^{133}$ Zekeriya Sertel, "Harp İçinde Bulunan İngiltere'nin Yakından Manzarası", Tan, 22 Eylül 1942, s. 4.

${ }^{134}$ Ahmet Emin Yalman, "Londra'dan Türkiye'ye”, Vatan, 19 Eylül 1942, s. 1.

${ }^{135}$ Ahmet Şükrü Esmer, "Lord Woolton'la Bir Konuşma", Ulus, 17 Eylül 1942, s. 3; Ahmet Emin Yalman,

"Londra'dan Türkiye'ye", Vatan, 17 Eylül 1942, s. 1.

${ }^{136}$ Ahmet Emin Yalman, "Londra'dan Ayrilırken”, Vatan, 30 Eylül 1942, s. 1.

${ }^{137}$ Hüseyin Cahid Yalçın, "Resmi Mülakatlar", Yeni Sabah, 11 Eylül 1942, s. 1; Ahmet Emin Yalman, "Londra'dan Türkiye'ye”, Vatan, 1 Birinciteşrin (Ekim) 1942, s.1.

${ }^{138}$ Ahmet Emin Yalman, "Londra'dan Türkiye’ye”, Vatan, 11 Eylül 1942, s. 1-3.

${ }^{139}$ Ahmet Şükrü Esmer, “Mr. Eden Türk Basın Heyetini Kabul Etti”, Ulus, 11 Eylül 1942, s. 3.

${ }^{140}$ Hüseyin Cahid Yalçın, "Resmi Mülakatlar", Yeni Sabah, 11 Eylül 1942, s. 1.

${ }^{141}$ Zekeriya Sertel, “Mr. Churçhill ile Mr. Eden'i Dinledikten Sonra”, Tan, 11 Eylül 1942, s. 1.

${ }^{142}$ Abidin Daver, "Çörçil Dün parlamentoda Türk Gazetecileri Kabul Etti”, İkdam, 11 Eylül 1942, s. 1-4.
} 
çalışmışlardır. Örneğin Abidin Daver, savaşın dördüncü yılı olmasına rağmen İngiltere'nin aç, hammaddesiz ve petrolsüz kalmadığını, tam aksine İngilizlerin her öğün üç tabak yemek yediklerini ve kıyafet konusunda yoksulluk çekmediklerini ve bundan dolayı da İngiltere'nin hayati maddelerin yokluğuyla mağlup edilemeyeceğini düşünmektedir ${ }^{143}$. Ayrıca gittikleri her yerde eşsiz bir hüsnükabul ve ne nezaket gördüklerini belirttikten sonra edindikleri Türkiye imajını aktarır: Bu Türkiye'ye karşı beslenen takdir ve hayranlı̆ğn bir tezahürü ve ifadesi idi... Türkiye’nin bütün Anglo-Sakson dünyasındaki itibarı, şerefi pek yüksektir. Bize bu mevkii temin eden, Büyük Milli Şefimiz Issmet Inönü'nün Türkiye Büyük Millet Meclisinin ve Cumhuriyet Halk Partisinin takip ettikleri dürüst ve temiz siyaset olmuştur. Her Türk yurttaşl, bundan biz Türk gazetecileri gibi, iftihar duymalıdır ${ }^{144}$.

Ahmet Emin Yalman'ın anlatımında İngiltere'de savaş koşulları, zahmet ve yükün eşit şekilde taksimi için sıkı tedbirler alındığı, herkese vücut sağlıklarını koruyacak kadar yiyecek verildiği ve giyecek payının ise temiz giyinmeye kâfi olduğu şeklidedir. Bununla birlikte ülkede savaşın sosyo-ekonomik durumu beklenenin aksinedir: Ortalıkta sıkıntıya benzer hiçbir şey yoktur, her tarafta güler yüzlü insanlara tesadüf ediliyor... İçimde harbin neticesine dair en küçük bir tereddüt varsa İngiliz ruhu ile temas ettikten ve serbest kanaate dayanan șevk ve mukavemetin derinliğini gördükten sonra bu da geçmiştir ${ }^{145}$. Ayrıca Londra için burast yurttan tatl bir parça hissini veriyord $u$ diyen Yalman, kendini Türkiye'de gibi hissetmiştir ${ }^{146}$.

Heyet reisi Hüseyin Cahid Yalçın da İngilizlerin gayretinden oldukça etkilenmiştir: Şimdiye kadar gördüklerimden, İngiliz milletinin harp gayreti uğrundaki çalışması üzerimde büyük bir tesir bırakmıştır ${ }^{147}$. Londra'nın yaralarını göstermekten korkmadığını ve bu yaralarından dolayı gurur duyduğunu söyleyen Yalçın, İngiltere'de halk arasında zengin-fakir diye bir ayrım kalmamışıır ${ }^{148}$. Yalçın'a göre İngiliz halkı sadece bir şey için yaşıyor: Savaşta galip gelmek.

Volume 12 Issue 6 Bunun için de ülkede lüks ve israf ortadan kalkmıştır. Halkın bu tevazu, sadelik ve fedakârlığı sevilmeye ve takdir edilmeye layıktır ${ }^{149}$. Ayrıca İngiltere'de Türklere karşı bir sempati vardır: Ingiltere'de konuştuğumuz herkeste memleketimize karşı hakiki bir takdir ve muhabbet duygular görmekle gerçekten bahtiyarız. Bir Türk olmaktan burada hakiki bir iftihar hissediliyor ${ }^{150}$. Savaşı kesin olarak Müttefiklerin kazanacağını kabul eden Yalçın'a göre Almanya, ne kadar kudretli olursa olsun müşterek İngiliz ve Amerikan kaynakları karşısında aciz kalmaya mahkûmdur ${ }^{151}$. Benzer şekilde Londra'da samimi dostluk tezahürleriyle karşılandıklarını belirten Ahmet Şükrü Esmer'in İngiltere'de ilk izlenimi, bazı bölgelerinin ağır tahribata uğramasına rağmen normal hayat kesintiye uğramamıştır. Bunun yanında "candan" kabul gördükleri bu şehirde Türk dostluğuna büyük k1ymet verilmektedir ${ }^{152}$. Esmer'e göre muharip memleketler içinde en iyi beslenen ülke İngiltere'dir. Ülkede zengin veya fakir herkesin evine giren gıda maddesi aynıdır ve giyim-kuşamda da bir sıkıntı yaşanmamaktadır ${ }^{153}$.

Zekeriya Sertel'in değerlendirmelerine bakılırsa İngiltere'de savaşın dördüncü yılı olmasına rağmen sanki daha yeni savaşa girilmiş gibi bir manzara vardır. Hayat her tarafta her bakımdan

\footnotetext{
${ }^{143}$ Abidin Daver, “Londra'da Müşahedeler”, İkdam, 16 Eylül 1942, s. 1-3.

${ }^{144}$ Abidin Daver, "Türkiye'nin Şeref ve İtibarı Pek Büyüktür”, İkdam, 12 Birincikânun (Aralık) 1942, s. 1-3.

${ }^{145}$ Ahmet Emin Yalman, "Londra'dan Türkiye'ye", Vatan, 6 Eylül 1942, s. 1-3.

146 Ahmet Emin Yalman, "Harp Sonrası Para Vaziyeti”, Vatan, 20 Eylül 1942, s.3.

${ }^{147}$ Vatan, 8 Eylül 1942, s. 1.

${ }^{148}$ Hüseyin Cahid Yalçın, "İngiltere’ye Giderken”, Yeni Sabah, 8 Eylül 1942, s. 1.

${ }^{149}$ Hüseyin Cahid Yalçın, "Londra'da Her Günkü Hayat", Yeni Sabah, 23 Eylül 1942, s.1.

${ }^{150}$ Hüseyin Cahid Yalçın, “İngilizler Türkiye’yi Nasıl Görüyorlar?”, Yeni Sabah, 3 Birinciteşrin (Ekim) 1942, s.1.

${ }^{151}$ Hüseyin Cahid Yalçın, "Harbi Kim Kazanacak?”, Yeni Sabah, 28 İkinciteşrin (Kasım) 1942, s.1.

${ }^{152}$ Ahmet Şükrü Esmer, "Basın Heyetimiz Çok Samimi Karşılandı”, Ulus, 6 Eylül 1942, s.1.

${ }^{153}$ Ahmet Şükrü Esmer, "Türk Gazetecilerinin Görüşlerine Göre İngiltere”, Ulus, 8 Eylül 1942, s. 1-4.
} 
normaldir. Oteller, lokantalar, sinemalar gece gündüz dolup taşmaktadır. Herkes neşeli, rahat ve gelecekten emin görünmektedir ${ }^{154}$. Sertel, savaşın dördüncü y1lında İngiltere'de göreceğini zannettiği sıkıntıları göremediği için hayretini gizlemez. Bununla birlikte savaş, halk arasında çok ciddi bir şekilde telakki edilmektedir ${ }^{155}$.

28 Eylül'de İngiltere'den ayrılıp 2 Ekim'de Amerika'ya ulaşan ${ }^{156}$ gazeteciler, 7 Aralık'ta Türkiye'ye döndü ${ }^{157}$. Gazeteciler gezi boyunca gazetelerine gönderdikleri yazılardan başka gezi dönüşünde de izlenimlerini yazı dizileri hâlinde okuyucularına ulaştırmıştır. Örneğin İkdam gazetesinin başmuharriri sıfatıyla İngiltere ve Amerika'ya davet edilen Abidin Daver 13 Ekim 1942 tarihinden sonra geziyle ilgili intibalarını Cumhuriyet gazetesinde neşretmeye başlamıştır. Bu konuyla alakalı olarak İkdam'da, biz de bundan böyle arkadaşımızı Cumhuriyetle baş başa bırakıyoruz şeklinde bir yaklaşımla Amerika'dan dönüşüne kadar İkdam başmuharrirliği unvanına sahip ve sırf bundan dolayı seyahate katılma firsatı elde eden Daver'in bu hareketi eleştirilmiştir ${ }^{158}$.

Neticede Aralık 1942'den itibaren gazetecilerin İngiltere ve Amerika izlenimleri Türk basınına yansımaya başlamışır. 10 Aralık 1942 tarihli Cumhuriyet gazetesinde Daver'in "Avrupa-Amerika İntibaları" yazı dizisinin yakında yayınlanacağı haberi okuyuculara duyurulmuştur. Zekeriya Sertel, 23 Aralık 1942 tarihinden itibaren Tan gazetesinde "Amerika ve İngiltere İntibaları" başlığı altında izlenimlerini neşretmeye başlamıştır. Hüseyin Cahid Yalçın, 7 Aralık 1942 günü Yeni Sabah'ta "Demokrasiler Diyarında" başlıklı yazı dizisine başlamıştır. Ahmet Şükrü Esmer de "Seyahat Notları" başlıklı yazı dizisinin ilkini 11 Aralık 1942 günü Ulus'ta yayımlamaya başlamıştır. Ahmet Emin Yalman ise gezi izlenimlerini sadece 6 ve 7 Aralık 1942 günlerinde "Seyahat Notları" başlığı altında yayımlayabildi. Çünkü 7 Aralık'ta Vatan gazetesi Charlie Chaplin'in Hitler ile alay etmek maksadıyla çektiği "Diktatör" filminden bir kareyi ilk sayfadan vermişti. Aynı sayıda Chaplin'in New York'ta bir radyoda Türk halkı için yaptığı bir konuşmanın özeti de yayımlanmıştı. Chaplin'in radyoda Nasrettin Hoca'nın "Bana mı inanıyorsun eşeğe mi?" fikrasını anlattıktan sonra Hitler kastedilerek "İnsanlara $\mathrm{m} ı$ inanacağız eşeklere mi?" yorumunun gazetede yayınlanması üzerine gazete, “açıkça kışkırtıcı yayın yaptığ $1{ }^{159 "}$ gerekçesiyle iki ay süreyle kapatılmıştır ${ }^{160}$.

\section{Sonuç}

Türkiye, İkinci Dünya Savaşı'ndan muharip etkileri dışında siyasi, sosyo-ekonomik ve kültürel anlamda doğrudan etkilenmiştir. Özellikle jeopolitik konumu nedeniyle savaşan devletler, Türkiye'yi kendi yanlarında savaşa dâhil edebilmek için büyük çaba sarf etmiştir. Fakat Türk hükümeti izlediği değişken politikalar sayesinde savaşın dışında kalmayı başarmıştır. Bunda izlediği denge politikasının etkisi büyüktür. Hükümet izlediği denge politikası gereği kontrolü elinde tutmak için özellikle basına karşı sıkı bir sansür uyguladı. Hükümet politikasına aykırı yayın yapan gazeteler bir telefonla kapatıldı. Ayrıca gazeteci milletvekilleri aracılığıyla kendi politik adımlarına paralel şekilde bir yayın politikası şekillendirdi. Benzer şekilde hükümet gibi gazetecilerin tutumu da savaşın seyrine göre değişkenlik göstermiştir.

\footnotetext{
${ }^{154}$ Zekeriya Sertel, "İngiltere Harbin Dördüncü Yılına Yani Bir İman ve Azimle Giriyor”, Tan, 6 Eylül 1942, s. 1-2.

155 Zekeriya Sertel, "Dördüncü Harp Yılına Girerken”, Tan, 26 Eylül 1942, s. 1-2.

${ }^{156}$ Vatan, 29 Eylül 1942, s.1; Vatan 2 Birinciteşrin (Ekim) 1942, s.1.

${ }^{157}$ Tan, 8 İlkkânun (Aralı) 1942, s.1.

${ }^{158}$ İkdam, 13 Birincikânun (Aralik) 1942, s. 1.

${ }^{159}$ Ulus, 9 İlkkânun (Aralık) 19452, s.1.

${ }^{160}$ Vatan, 7 İlkkânun (Aralık) 1942, s.1; Yalman, Gördüklerim Geçirdiklerim, C. II, s. 1225-1226; Kızılca, "1942

Y1lında Mihver ve Müttefik Devletlerce...”, s. 24.
} 
Savaşın başında yani Mihver devletlerin üstün olduğu dönemde tarafsız olan Türkiye, Alman yanlısı bir politika izlemiştir. Buna karşın savaşın ilerleyen dönemlerinde yani Müttefiklerin güçlendiği dönemde bu ülkelere yakınlaşmıştır. Hiç kuşkusuz bu sürecin en somut yansıması basın olmuştur. Bu bakımdan gazetecilerin gerçekleştirdikleri yurt dış1 gezileri tarafsızlık politikasının başarılı bir şekilde uygulanmasını isteyen hükümet için büyük bir öneme sahipti. Hükümet, farklı gruplardan oluşan gazetecileri iki düşman bloğa da göndererek denge politikası izlemeye devam etti ve bu politikayı riske atmayacak gazetecileri seçmeye de büyük özen gösterdi. Bu amaçlar ve dış politikanın gereği olarak gazeteciler, Londra gezisinde İngiltere'yi, Berlin gezisi sırasında Almanya'yı öne çıkaran yazılar kaleme ald1. Özellikle 1942 Londra gezisinde gerek gazeteciler gerekse İngiliz yetkililer sık sık Türkİngiliz dostluğunu gündeme getirmiştir. Ayrıca gazeteciler, hem kamu görevlisi gibi hükümetten para aldılar hem de gittikleri ülkeleri destekleyen yayınlar yaptılar. Her ne kadar hükümetin belirlediği çizgiyi aşamasalar da gittikleri ülkelerin hayranlık duydukları taraflarını gazete sütunlarına taşıyarak Türk kamuoyunu etkilemeye çalışmışlardır. Netice itibariyle başlangıcından sonuna kadar karşılıklı hükümetlerin planladığı ve kontrolü altında yapılan bu geziler, bağımsız şeklide ve derinlemesine sosyal, ekonomik, siyasi ve askerî gözlem/değerlendirme/analizleri ortaya koymasa da gerek savaş süresince ülkelerin politik adımlarının anlaşılmasına katkı sunmuş, gerekse sınırlı olarak savaş koşullarını yansıtmıştır.

\title{
Kaynakça
}

\section{Süreli Yayınlar}

\section{A- Resmi Yaymlar}

Türkiye Büyük Millet Meclisi Tutanakları (Zabıt Ceridesi)

\section{B-Gazete ve Dergiler}

\author{
Akşam \\ Cumhuriyet \\ İkdam \\ Kebikeç \\ Milliyet \\ Tan
}

Türk Sözü

Ulus

Vakit

Yeni Asır

Yeni Sabah

Vatan

\section{Kitaplar ve Makaleler}

A. Kitap ve Tezler

AKANDERE, Osman, Milli Şef Dönemi 1938-1945, İz Yay., İstanbul 1998. 
İkinci Dünya Savaşı́nda Türk Gazetecilerin Londra ve Berlin Gezileri ve İzlenimleri (1939-1942)

ARAL, Ahmet Erman, Kültür Propagandasindan Kültürel Diplomasiye: British Council'in Türkiye'deki Faaliyetlerinin 1940-1950 ve 2005-2014 Dönemlerinde Karşılaştırmalı Incelemesi, (Hacettepe Üniversitesi Sosyal Bilimler Enstitüsü, Yayımlanmamış Yüksek Lisans Tezi), Ankara 2014.

ARMAOĞLU, Fahir, 20. Yüzyıl Siyasi Tarihi, Timaş Yay., İstanbul 2016.

AYDEMIR, Şevket Süreyya, İkinci Adam, C. II, Remzi Kitabevi, İstanbul 2011.

AYDOĞMUŞ, Fatih, İkinci Dünya Savaşı Sürecinde Propaganda ve Türkiye, (İstanbul Üniversitesi, Atatürk İlkeleri ve İnkılâp Tarihi Enstitüsü, Yayımlanmamış Doktora Tezi), İstanbul 2018.

BOYKOY, Seher, II. Dünya Savaşı Yıllarında Türkiye'nin Sosyo-Kültürel Yapısı, (Dokuz Eylül Üniversitesi, Atatürk İlkeleri ve İnkılâp Tarihi Enstitüsü, Yayımlanmamış Doktora Tezi), İzmir 2008.

ÇAVDAR, Tevfik, Türkiye'nin Demokrasi Tarihi 1839-1950, İmge Kitabevi, 2. Bask1, Basım yeri ve yıli yok.

DERINGiL, Selim, Denge Oyunu, İkinci Dünya Savaşında Türkiye’nin Dış Politikası, Tarih Vakfi Yurt Yay., İstanbul 2014.

GÜZ, Nurettin, Serbest Cumhuriyet Firkası Sonrası Basında Muhalefet ve 1931 Matbuat Капиnu, Gazi Üniversitesi İletişim Fakültesi Basımevi, Ankara 1993.

HART, Basil Liddel, İkinci Dünya Savaşı Tarihi, Çev. Kerim Bağrıaçık, İş Bankası Kültür Yay., İstanbul 2015.

Topuz, Hıfzı, 100 Soruda Türk Basın Tarihi, Gerçek Yayınevi, İstanbul 1973. II. Mahmut'tan Holdinglere Türk Basin Tarihi, Remzi Kitabevi, İstanbul 2003.

KABACALI, Alpay, Türk Basınında Demokrasi, TC Kültür Bakanlığı Yay., Ankara 1999.

KOÇAK, Cemil, Türkiye'de Milli Şef Dönemi 1938-1945, C. I. , İletişim Yay., İstanbul 1996.

KOLOĞLU, Orhan, Osmanlıdan Günümüze Türkiye'de Basın, İletişim Yay., İstanbul 1992.

NADİ, Nadir, Perde Aralı̆̆ından, Çağdaş Yay., İstanbul 1979.

SELÇUK ŞİRIN, Funda, Falih Rıfkı Atay (1893-1950), (Ankara Üniversitesi, Sosyal Bilimler Enstitüsü, Yayımlanmamış Doktora Tezi), Ankara 2009.

SERTEL, Zekeriya, Hatırladıklarım, Remzi Kitabevi, İstanbul 2001.

TUNCER, Hüner, İsmet İnönü’nün Dış Politikası 1938-1950, Kaynak Yay., İstanbul 2012.

US, Asım, 1930-1950 Hatıra Notları, Vakit Matbaası, İstanbul 1966.

, Hatıra Notları, Haz. İsmail Dervişoğlu, Kitabevi, İstanbul 2012.

YALMAN, Ahmet Emin, Yakın Tarihte Gördüklerim ve Geçirdiklerim, C. II, Yay. Haz. Erol Şadi Erdinç, İstanbul 1997.

YILDIZ, Aytaç, Burhan Asaf Belge: Cumhuriyetin Erken Döneminde Aydın ve İktidar İlişkisi, (Ankara Üniversitesi, Sosyal Bilimler Enstitüsü, Yayımlanmamış Doktora Tezi), Ankara 2009. 


\section{B. Makaleler}

AKIN, Nur Özmel, "1942 Y1lında Türk Gazetecilerin İngiltere Gezisi”, Tarih ve Toplum, S. 189 , ss. 132-136.

ATAY, Falih Rıfk1, “Asker İngiltere”, Ulus, 25 Haziran 1939, s.8.

, "Büyük Tehlike Günleri”, Ulus, 3 Haziran 1940, s. 2.

, “Ceb’eDoğru”, Ulus, Haziran 1940,s. 2.

, “Taarruz Sabah1”, Ulus, 1 Haziran 1940, s. 2.

, “Umumi Hava”, Ulus, 23 Haziran 1939, s. 1.

, “Gazeteci Mesleği”, Ulus, 29 Haziran 1938, s. 7.

AYDIN, Mustafa, "İkinci Dünya Savaşı ve Türkiye 1939-1945”, Edt. Baskın Oran,Türk Dış Politikası, C.I, İletişim Yay., İstanbul 2009, ss.399-475.

BAĞCE,Emre, "Milli Şef Döneminde İktidar-Basın İlişkisi”, Medyave Siyaset 2: 1923-1946

Tek Partili Dönem, Der., Tolga Yazıcı, Volga Yay., Kocaeli 2016, ss. 87-126.

BELGE, Burhan, “İngiltere Silahlaniyor”, Ulus, 1 Temmuz 1939, s. 2.

, “İngiliz Balilla’ları”, Ulus, 26 Haziran 1939, s.2.

, "Londra'ya Varış", Ulus, 23 Haziran 1939, s.2.

"Londra Yolunda",Yeni Asır, 19 Mayıs 1940, s. 1-2.

Volume 12

ÇELIK, Ahmet, “İkinci Dünya Savaşı'nda Hükümet-Basın İlişkileri ve Gazeteci Mebuslar”, Frrat Üniversitesi Sosyal Bilimler Dergisi, Cilt: 28, Say1: 2, Temmuz 2018, ss.315-331.

DAVER, Abidin “Londra'da Karşıllaştığımız Hava”, Cumhuriyet, 5 Haziran 1939, s 3. , “Üç Portre”,Cumhuriyet, 16 Haziran 1939, s. 5. ,“Anglo-Sakson Âlemine Doğru”, İkdam, 21 Ağustos 1942, s. 3.

, “Londra'da Müşahedeler”, İkdam, 16 Eylül 1942, s. 1-3.

, “Türkiye'nin Şeref ve İtibarı Pek Büyüktür”, İkdam, 12 Birincikânun (Aralık) 1942, s. 1-3. s. 1-4. , “Çörçil Dün Parlamentoda Türk Gazetecileri Kabul Etti”, İkdam, 11 Eylül 1942,

ENGIN, Vahdettin,"II. Dünya Savaşı ve Türkiye”, Yay. Haz. Nesrin Sarıahmetoğlu - İlyas Kemaloğlu, Íkinci Dünya Savaşı ve Türk Dünyası, Türk Dünyası Belediyeler Birliği Yay., İstanbul, 2016, ss. 249-257.

ESMER, Ahmet Şükrü, "Bir Seyahat'in Notları”, Ulus, 2 Haziran 1940, s.3. , "Bir Seyahat'in Notları", Ulus, 3 Haziran 1940, s.3. , "Bir Seyahat'in Notları", Ulus, 4 Haziran 1940, s.3. , "Basın Heyetimiz Çok Samimi Karşılandı", Ulus, 6 Eylül 1942, s.1. , “Türk Gazetecilerinin Görüşlerine Göre İngiltere”, Ulus, 8 Eylül 1942, s. 1-4. “Mr. Eden Türk Basın Heyetini Kabul Etti”, Ulus, 11 Eylül 1942, s. 3. 
İkinci Dünya Savaşı'nda Türk Gazetecilerin Londra ve Berlin Gezileri ve İzlenimleri (1939-1942)

, “Mr. Çörçil’le Türk Gazetecilerin Bir Görüşmesi”, Ulus, 15 Eylül 1942, s. 3.

, “LordWoolton'la Bir Konuşma”, Ulus, 17 Eylül 1942, s. 3.

, "Bombalar Altındaki Londra'da", Ulus, 13 İlkkânun (Aralık) 1942, s.2.

"İngiltere'de İç Politika Durumu”, Ulus, 18 İlkkânun (Aral1k) 1942, s. 2.

FENIK, Faruk, “Gazetecilerimiz Almanya'dan Döndüler”, Vatan, 17 Ağustos 1942, s.1-3.

GLASNECK, Johannes, “Alman Faşizminin Türkiye'deki Propaganda Faaliyetleri”, Çev.

Murat Çakır, 1966 yllında Halle'deki Martin-Luther-Üniversitesi'nin “Wissenschaftliche Beiträge" adlı dizininde yayımlamıstır, ss.1-14.

GÖZ, Ali Cem, "İkinci Dünya Savaşı Yıllarında Türkiye'de Siyasal İktidar Tarafından Kapatılan Basın Organları Bağlamında Bir Listeleme Denemesi”, Süleyman Demirel Üniversitesi Vizyoner Dergisi, C.3, S.5, 2011, ss 1-12.

GÜVEN, Nevzad, “Alman Propaganda Nazırı İle Görüşme”, Türk Sözü, 22 Ağustos 1942, s.1. , “Almanya'daki Hayat”, Türk Sözü, 27 Ağustos 1942, s.1-3.

, “Ren'de Bir Dolaşma”, Türk Sözü, 2 Eylül 1942, s.1.

, "Savaştaki Almanya”, Türk Sözü, 21 Ağustos 1942, s.1.

İLGAZİ, Abdullah,"İkinci Dünya Savaşı'nın İç Politikadaki Yansımaları: Yaşanan Siyasi ve Ekonomik Sorunlar", Eskişehir Osmangazi Üniversitesi Sosyal Bilimler Dergisi, Aralık 2019, 20(2), ss. 259-267.

KARAGÖZ KIZILCA, Gül, “1942 Y1lında Mihver ve Müttefik Devletlerce Düzenlenen Türk Basın Gezileri”, Kebikeç, 14, 2002, ss.5-27.

NADİ, Nadir, “1000 Senelik Bir Dramın En Feci Dakikaları”, Cumhuriyet, 7 Haziran 1940, s.3. , “505 Sayılı Korugan”, Cumhuriyet, 27 Ağustos 1942, s. 3.

"Alman Ordusunda Yeni Ruh ve Yeni Savaş Birlikleri”, Cumhuriyet, 23 Ağustos 1942, s. 1. , “Amirallik 1. Lordu ve Kuru Yemişlerimiz”, Cumhuriyet, 6 Haziran 1940, s. 3. , “Berlin'de Hayatın Manzarası”, Cumhuriyet, 19 Ağustos 1942, s. 1-3.

, “Göbbels'le Bir Saat”, Cumhuriyet, 21 Ağustos, 1942, s. 1-3.

, “İngiltere’ye Geçerken”, Cumhuriyet, 5 Haziran 1940, s. 5.

ORAN, Baskın, "Savaş Kaosunda Türkiye, Göreli Özerklik-2”, Edt. Baskın Oran,Türk Dış Politikası, İletișim Yay., İstanbul 2009, ss. 387-398.

ÖZÇELIK, Mücahid, "İkinci Dünya Savaşı'nda Türk Dış Politikası", Erciyes Üniversitesi Sosyal Bilimler Enstitüsü Dergisi, 1.29 (2010), ss.253-269.

SADAK, Necmettin, "İtalya Niçin Hala Harbe Girmiyor", Akşam, 3 Haziran 1940, s. 1-5.

"Topyekûn Harbin Ne Demek Olduğunu Almanya'da Gördüm”, Akşam, 19 Ağustos 1942, s. 1.

, "Harp Ortasında Bir Aylık Yolculuktan Dönüş”, Akşam, 17 Ağustos 1942, s. 1.

, “İki Milleti İçinden Gördük”, Akşam, 31 Mayıs 1940, s. 1. 
SERTEL, Zekeriya, "İngiltere Harbin Dördüncü Yılına Yani Bir İman ve Azimle Giriyor", Tan, 6 Eylül 1942, s. 1-2. , "Mr. Churchill ile Mr. Eden'i Dinledikten Sonra", Tan, 11 Eylül 1942, s. 1. , "Harp İçinde Bulunan İngiltere’nin Yakından Manzarası”, Tan, 22 Eylül 1942, s.

4. , “Dördüncü Harp Y1lına Girerken”, Tan, 26 Eylül 1942, s. 1-2.

US, Asım, “Umumi Vaziyete Bir Bakış”, Vakit, 31 Mayıs 1940, s. 1-5. , “Almanya Disiplin Memleketi”, Vakit, 22 Ağustos 1942, s. 1-2. , "Harbe mi Sulha mı?", Vakit, 8 Haziran 1939, s. 1-2. , “İftihara Değer Müşahedeler”, Vakit, 14 Haziran 1939, s. 1-2. , "Londra Yolunda", Vakit, 29 Mayıs 1939, s.1,8. , “Münih’te Türk Caddesi”, Vakit, 1 Ekim 1942, s. 1. , “Taarruz Haberi Paris’te Nas1l Duyuldu?”, Vakit, 19 Mayıs 1940, s.1. , “Zigfrid Hattından Nasıl Geçtik?”, Vakit, 13 Eylül 1942, s. 1. , “Italya Harbe Girecek mi?”, Vakit, 1 Haziran 1940, s. 1-4.

YALÇIN, Hüseyin Cahid, “İngiltere'de Türk Gazetecileri”, Yeni Sabah, 18 Haziran 1939, s. 3. ,"Sulhe Varmak İçin”, Yeni Sabah, 17 Haziran 1939, s. 1. , “İngiltere’ye Giderken”, Yeni Sabah, 8 Eylül 1942, s. 1. , “Resmi Mülakatlar”, Yeni Sabah, 11 Eylül 1942, s. 1. , “Çörçil'le Mülakat”, Yeni Sabah, 16 Eylül 1942, s.1. , “Londra'da Her Günkü Hayat”, Yeni Sabah, 23 Eylül 1942, s.1. , “Harbi Kim Kazanacak?”, Yeni Sabah, 28 İkinciteşrin (Kasım) 1942, s.1. , “İngilizler Türkiye’yi Nasıl Görüyorlar?”, Yeni Sabah, 3 Birinciteşrin (Ekim) 1942, s.1.

YALMAN, Ahmet Emin, “Londra'dan Türkiye'ye”, Vatan, 6 Eylül 1942, s. 1-3. , “Londra'dan Türkiye'ye”, Vatan, 11 Eylül 1942, s. 1-3. , “Çörçil’le Görüşürken”, Vatan, 14 Eylül 1942, s. 1-3. , “Londra'dan Türkiye'ye", Vatan, 17 Eylül 1942, s. 1. , “Londra'dan Türkiye'ye”, Vatan, 19 Eylül 1942, s. 1. , Harp Sonrası Para Vaziyeti”, Vatan, 20 Eylül 1942, s.3. , “Londra'dan Ayrilırken”, Vatan, 30 Eylül 1942, s. 1. , “Londra'dan Türkiye'ye”, Vatan, 1 Birinciteşrin (Ekim) 1942, s.1. 
İkinci Dünya Savaşı'nda Türk Gazetecilerin Londra ve Berlin Gezileri ve İzlenimleri (1939-1942)

YETKIN, Barış, “1945-1950 Arası Demokratikleşme Sürecinde Basın”, Yakın Dönem Türkiye Araştırmaları, 17-18. 2010, ss.1-28.

YILDIRIM, Özlem, “İkinci Dünya Savaşı Sürecinde Türk Basınında Mihver Taraftarlığı ve Hükümetin Bakışı",Türk Basın Tarihi Uluslararası Sempozyumu, C. III, Atatürk Araştırma Merkezi Yayınları, Ankara 2018, ss. 1705-1755.

YÜMLÜ, Murat, “Yarım Asra Ulaşan Basın Emeği Işığında Gazeteci Abidin Dâver”, Türkiyat Mecmuast Journal of Turkology, c. 29/1, 2019, ss. 249-299. 